Article

\title{
Development of an Integrated Design Strategy for Blue-Green Architecture
}

\author{
Friederike Well *(D) and Ferdinand Ludwig (D)
}

Citation: Well, F.; Ludwig, F Development of an Integrated Design Strategy for Blue-Green Architecture. Sustainability 2021, 13, 7944 https://doi.org/10.3390/su13147944

Academic Editors: Nikos A. Salingaros and Marc A. Rosen

Received: 21 May 2021

Accepted: 11 July 2021

Published: 16 July 2021

Publisher's Note: MDPI stays neutral with regard to jurisdictional claims in published maps and institutional affiliations.

Copyright: (c) 2021 by the authors. Licensee MDPI, Basel, Switzerland. This article is an open access article distributed under the terms and conditions of the Creative Commons Attribution (CC BY) license (https:/ / creativecommons.org/licenses/by/ $4.0 /)$.
Department of Architecture, School of Engineering and Design, Technical University of Munich, 80333 München, Germany; ferdinand.ludwig@tum.de

* Correspondence: friederike.well@tum.de; Tel.: +49-89-289-22570
Abstract: Blue-green architecture entails buildings that contribute to improving the urban climate through the synergetic combination of water management and vegetation. They are part of an urban blue-green infrastructure network that combines ecosystem services in a multifunctional way. Projects implemented in an interdisciplinary manner create synergies with regard to the combination of waterrelated and vegetation-related objectives. However, applicable design strategies for this approach are currently lacking in practice. This paper investigates the approach of a blue-green architectural project in Stuttgart (the so called "Impulse Project") and derives insights for an integrated design strategy. The analysis and transfer of the research is carried out by using the research by design methodology. For this purpose, the interdisciplinary design process is divided into three phases (pre-design, design, post-design) and described in detail. Reflection on the documented design reveals the knowledge gained and enables the transfer of the findings to future projects by means of the integrated design strategy for blue-green architecture.

Keywords: blue-green systems; building greening; water management; integrated planning; research by design; design strategy; grey water; climate adaption

\section{Introduction}

The concept of blue-green infrastructure (BGI) has been proven to have many positive impacts on the urban environment, the local population and the microclimate [1,2]. Urban development leads to strong interventions in the natural water cycle. The high level of sealing leads to a changed water regime with high runoff, and low retention and evapotranspiration on site [3]. These circumstances have a negative effect on environmental conditions. This also includes the fact that the air and surface temperature in cities tends to be higher than in the surrounding areas (Urban Heat Island Effect). Climate change will further intensify this effect [3]. Projects that are realised according to the principles of BGI provide important ecosystem services in cities, and thus significantly contribute to climate adaptation and resilience strategies. Especially during extreme weather conditions, blue-green systems provide a balancing and mitigating function [4]. Natural and seminatural spaces, unlike sealed surfaces, can absorb a lot of water in the event of heavy precipitation, and thus prevent against flooding. At the same time, these areas can release stored water in the case of prolonged heat and drought, providing evapotranspiration that improves the microclimate [5]. In addition to the mitigation effect at extreme weather events, BGI contributes to the constant improvement of environmental conditions in cities. This includes, for example, increasing biodiversity, improving hydrological processes such as groundwater recharge through infiltration, recreational value for the population, and establishing a green building culture [1,2].

The term blue-green architecture (BGA) refers to the application of BGI at the building scale [6]. These projects focus on a building and its surrounding open spaces, in contrast to larger urban projects such as parks and river courses. The combination of comprehensive (building) greenery with sustainable water management offers numerous ecological and 
climatic benefits [7]. A two-sided approach that considers and addresses the aspects of water availability (e.g., the disposal problem during heavy rainfall) and those of water demand (e.g., for irrigation), simultaneously from the start of planning, is necessary to achieve an effective and synergetic design [6]. This requires the expertise of all relevant disciplines to be integrated into a collaborative process. Dreiseitl [8] describes the importance of cross-disciplinary planning for blue-green infrastructure, which is also applicable to blue-green architecture: "Increasing density will help us focus on a more holistic and integrated approach to Blue-Green Infrastructures, with the aim of sharing spaces with different functions. This in turn necessitates that we overcome disciplinary boundaries and better integrate all design and planning processes." [8]

This study describes the interdisciplinary planning process for a blue-green architecture project that combines urban greening aspects with on-site water management. From the findings of the planning and implementation, a design strategy for planners is developed to support the process in future projects and to ensure the greatest possible synergies in regard to the project-specific objectives.

\subsection{State of the Art: Architectural Planning Process and Integrated Planning}

Commonly, the design process in architecture is linear. The first stage of the project is the spatial programme, on the basis of which the architect designs the building. In the implementation planning phase, the specialist planners become involved and solve any technical issues relevant to the implementation. The essential design aspects are already decided at this stage, and thus set the direction. Accordingly, the decision-making authority lies with the architect. The requirements for building projects have become steadily higher and more complex, not least because of energetic requirements which considerably increase the amount of building services engineering [9]. In this context, the principle of integrated planning has been established [10] (p. 10), meaning the early involvement of specialist planners, particularly engineers. The restructuring of the process makes planning more effective, as problems can be identified earlier and integrated into design solutions. For example, energy requirements have a major impact on building shape, orientation, windows, wall thickness, etc.

The concept of blue-green infrastructure is described in the literature, but still has little application in practice. There is a lack of concrete guidance describing, not only the goals and benefits of blue-green projects, but also the integrated approach to implement vegetation and water management at the building level. Especially in this field, an innovation in planning is needed to meet the complex challenges that come along with climate change. A disciplinary approach cannot adequately cover the areas of concern $[6,11]$. Within the field of sustainable building, descriptions of interdisciplinary planning processes are found, which refer to the effective integration of energy concepts and technical building equipment. These procedures were, therefore, partly used as references, although they are not fully transferable to blue-green systems.

Heidemann et al. [12] describe the procedure of integral planning of technical building equipment over the entire life cycle (design, planning, construction, operation and use). While these approaches aim to optimise workflows and reduce costs with a focus on energy efficiency, blue-green architecture creates synergy through aspects such as evaporation, urban climate and biodiversity. Despite these differences it can be assumed that bluegreen architecture will also benefit from the early involvement of specialised planners, and thereby integrated planning for blue-green architecture offers the possibility to pursue aesthetic, ecological and climatic goals in equal measure.

\subsection{Impulse Project and Research Question}

This study is based on the planning and implementation of the 'Impulse Project' in Stuttgart, Germany. The temporary architectural structure is part of the research project INTERESS-I (Integrated Strategies for Strengthening Urban Blue-Green Infrastructures), which is funded by the German Federal Ministry of Education and Research. The conditions 
for the Impulse Project have been specified in the research proposal. The intention was to implement a synergetic blue-green approach on a compact scale and to thereby test out an integrated blue-green design process. Thus, the project serves the research process and the validation of the underlying strategy of integrated planning. In addition, it provides a platform for communication and demonstration of the overall project goals. Later in the project progress, the Impulse Project will also be evaluated for its effectiveness on microclimate, heavy rainfall management and the use of alternative water resources. The quantitative measurements are not part of the present study, which focuses exclusively on the integrated approach and the planning work in the interdisciplinary team, following a qualitative approach according to the method "research by design" (see Section 2).

With regard to the transferability of the findings from the planning process, the following limitations should be mentioned: In terms of the planning team and the planning procedure, the Impulse Project reveals deviations from a conventional construction process. For one, as it is a research initiative, there is no "client" in the classical sense. The planning team defines the framework programme and objectives themselves, and thus becomes its own client. At the same time, the planning team also assumes the role of the users, as the built result serves research and evaluation. For example, various measurements are carried out during the utilisation phase, and system operation is varied in order to detect changes in the effect. These differences to the conventional construction process are considered and described in detail in the discussion, due to their effect on the application of the design strategy in practice.

Two sets of research questions underlie this study:

First: How does the integrated blue-green design process look in application? In which steps does the process take place? How does the interaction in the interdisciplinary team evolve and what unforeseen difficulties arise? How do decision-making processes work and what positive results are achieved by the integrated approach?

Second: What general findings for integrated blue-green planning can be derived? How can they be applied to further projects? Which strategies have to be created for a successful implementation of blue-green architecture projects?

The findings of the analysis are used to develop a strategy for integrated blue-green architectural design. This general approach is a guideline for blue-green projects and describes step by step the application of integrated planning.

\section{Materials and Methods}

This paper follows a design-based approach. It refers to a procedure in which design is the basis and method of research. The process of designing drives knowledge acquisition. The principles on which design, and thus also architectural research, are founded, are particularly suitable for finding creative solutions to complex problems $[13,14]$. Designers always work iteratively and seek non-linear possibilities instead of one-dimensional solutions [15] (p. 60 f.). This leads to a knowledge production that can be made visible through reflection. In this sense, it is a qualitative research methodology $[16,17]$ with an inductive research approach [18].

Concerning the Impulse Project, we proceeded as follows: Starting from the research question, the design and the 1:1 implementation were developed together with the project partners. The course of action was documented and the following reflection of such action enabled its abstraction to a wider applicable design strategy (Figure 1). 


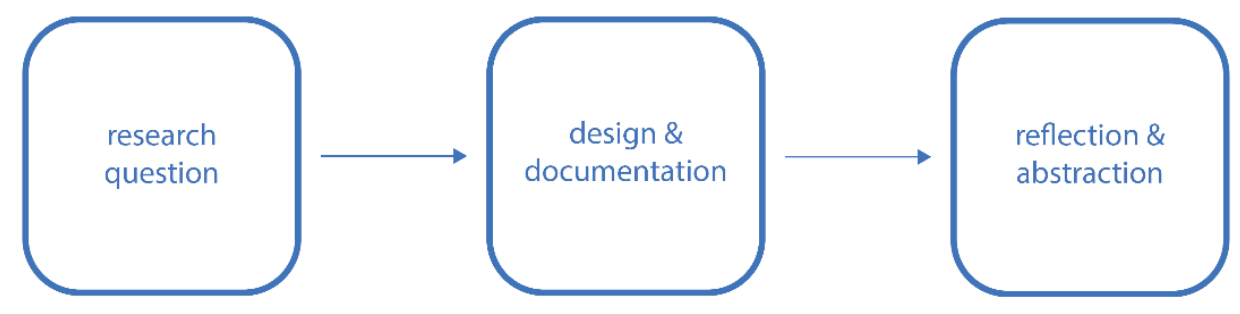

Figure 1. Design-based approach for the Impulse Project.

The methodological approach shows clear references to research by design, also known as research through design. The definitions for this concept vary in the literature. One reason for this is that it is a broad-based method that is in constant development [19]. In this paper, we refer to the analysis of Roggema [20], in which many findings on design-based research have been incorporated. Based on the analysis of several studies, Roggema has developed a method that divides research by design into three phases. The full definition is as follows:

"Research by design is a method, which uses design to research spatial solutions for a certain area, accommodating a design process, consisting of a pre-design phase, a design phase and a post-design phase, herewith providing a philosophical and normative basis for the design process, allowing to investigate the qualities and problems of location and test its (spatial) potentials, meanwhile creating the freedom to move with the proposals in uncharted territory, and producing new insights and knowledge interesting and useful for a wide audience." [20]

According to this definition, the three phases of the Impulse Project were identified.

1. Pre-design phase: In this phase the goal of the blue-green project was defined and the question of integrated planning was developed. Particularly important was the initial communication among architects, specialist planners and experts in order to develop a common understanding of the project and the planning task. Introductions to the technical basics (grey water treatment, irrigation technology) expanded the interdisciplinary knowledge of all participants. Additionally, the framework conditions and limiting factors (location, financial scope, users) were identified.

2. Design phase: The second phase consisted of the design process for the Impulse Project. The technical and spatial solutions were evolved in iterative loops by the interdisciplinary team in order to coordinate blue and green aspects synergistically. In accordance with the integrated approach, the architectural design was created in close interaction with the "blue" and "green" representatives. Working together on an implementation project enabled the team to learn from experience. The physical implementation is an elementary part of the research process, because some problems do not arise until the construction phase. During the development of a prototype, it is possible that theoretical considerations cannot be implemented in practice, or, for example, weak points are overlooked. In order to understand the development of the Impulse Project, the process was documented in detail. This included extensive protocols of meetings and discussions, as well as e-mails and notes of telephone calls. This documentation allowed to highlight the questions that arose amongst the planning partners and how they dealt with them. The roles of the participants could thus be identified, and it became clear who contributed to the different parts of the overall process and at which stage.

3. Post-design phase: Investigating the transfer of the insights from the Impulse Project to subsequent projects and outlining the integrated approach form the third phase of the study. According to Roggema's definition, research and design are decoupled in this phase. The critical reflection of the completed project and the analysis of the blue-green integrated design frame the research output on an academic level. The development of a design strategy transposes the findings from the Impulse Project into future blue-green projects. 


\section{Results}

This section describes the results of the entire research by design process following the three phases described above. Planning for the Impulse Project started at the end of 2018 with the first meetings of the project team and intensified in 2019. The implementation followed in autumn 2019 and was delayed due to restrictions caused by the COVID-19 pandemic. Therefore, the commissioning took place belatedly in early summer 2020 . The reflection and transfer of the results took place throughout the year 2020.

\subsection{Pre-Design Phase: Framework Conditions for Design}

\subsubsection{Local Situation and Site Search}

The site of the Kunstverein Wagenhalle e.V. in Stuttgart, an area with a huge former coach depot used by artists, had already been determined as the location for the Impulse Project before the overall research project started. However, the exact location was not specified. Next to the old coach depot, there are other facilities on the site: The so called Container City hosts several workshops and studios, and was built in direct vicinity of the historic hall in 2016/17. Adjacent to the Container City, the urban gardening project Stadtacker Wagenhallen e.V. is located. This creative environment provides an ideal neighbourhood for the Impulse Project for several reasons. For one, with its temporary architecture, the Container City corresponds to the planned appearance of the Impulse Project. Right from the start, a temporary and mobile solution based on reused overseas containers was envisaged. In addition, there are temporary worker accommodations (residential containers) on the site that had been installed in the context of a tunnel construction site, which belongs to the Stuttgart 21 railway and urban development project. The entire site is part of the future Maker city in the Rosenstein quarter and an integral part of the International Building Exhibition IBA 2027 [21]. The implementation of the Impulse Project, therefore, not only aims to improve a given situation, but seeks to stimulate blue-green urban development in the long term.

The beginning of the pre-design phase was marked by the search for the definite location of the Impulse Project. In a pre-selection, nine possible spots were identified. The immediate neighbours (artists, construction workers, urban gardeners) and their interests were included in the decision, but the decisive factors for the spatial criteria entailed the accessibility, the available space, the structural subsoil, the visual relationship to the existing buildings and the environmental influences. On the basis of this, two positions were shortlisted which had different advantages and disadvantages: a very prominent position at the entrance to the Container City, which was considered the favourite right from the start, and a second, quieter location at the back of the residential containers in proximity to the urban gardening project and a large weeping willow (compare Figure 7). From the very beginning, it was determined that the Impulse Project could only carry out concrete interventions on a small area. Changes (such as the installation of green roofs or the creation of water patches) in the area of the Container City and the urban gardening project were ruled out due to the terms of use and legal framework conditions. Furthermore, solutions that require a major intervention in the ground, such as ponds, underground cisterns or ground-based plantings, were ruled out due to the temporary nature of the project.

\subsubsection{Site-Related Pre-Conditions for Water and Vegetation}

In the sense of a two-sided blue-green approach, it was necessary at this point to identify the respective problems and framework conditions for the design task. A distinction must be made between overarching and project-specific goals. Overarching goals include, for example, improving the microclimate through intensive greening (evaporation) and contributing to stormwater management through integrated retention. The extent to which the project-specific conditions can offer solutions here remained to be determined by identifying the conditions on site. 
In regard to the project-specific goals, the analysis of the surroundings showed that there existed two water flows that could be incorporated into the design on the "blue" side and would have to be taken into account for further considerations. Both water flows are related to the residential containers: the rainwater runoff from the rooftops and the wastewater from the showers and hand basins, so called "grey water". Grey water is defined as slightly polluted wastewater that is free of faeces and can be treated easily to process water [22] (p. 146 f.). The sanitary rooms have exterior installations that can be accessed without major construction effort. This allowed to make the grey water available to the Impulse Project. With its large sheet metal roof, the container housing facility at the same time represents extensive surface sealing that can contribute to overloading the sewer system during storm water events. The storage of rainwater for irrigation purposes is, therefore, also linked to the goal of helping to relieve the burden on the sewer system [6]. In summary, rainwater and grey water both remain unused as a resource and are discharged. Local reuse would contribute to a sustainable water management.

Also on the "green" side, basic potentials for improvement were identified. In the existing vegetation, the large weeping willow and the urban gardening were particularly prominent. The weeping willow seems to cover its water needs independently via deep roots. The urban gardening project, on the other hand, has a high irrigation demand in summer, which is partly covered by rainwater and partly by drinking water. The potential for greening buildings was also identified: both the façade of the residential containers and the roofs of the small surrounding huts were revealed as possible greening surfaces. Also, innovative forms of freestanding vertical greenery to further enhance the site were considered.

The treatment of grey water by a constructed wetland planted with reeds, as well as the irrigation needs of (vertical) greening, could provide opportunities to link blue and green aspects and to create synergies. Although some of these possible interfaces between water and vegetation became visible at that point, no design solution for the planning task was developed. The intention of this was to first interlink the project goals synergetically in order to explore design solutions on this basis.

\subsubsection{Planning Team}

The interdisciplinary blue-green planning and research team for the Impulse Project in Stuttgart consisted of four parties (Figure 2). All participants belong to the overall INTERESS-I research project and received funding in this context. The coordination of the planning and implementation process, as well as the responsibility for the architectural design and the integration of the blue and green elements into one system, remained with the Technical University of Munich (TUM). The University of Stuttgart (ISWA) took on the task of determining the available water quantities, as well as the storage modelling and control. The Technical University of Kaiserslautern (TUK) was part of the "blue team", but regarding water quality and water treatment. The "green" part was taken over by the horticultural enterprise Helix Pflanzen GmbH (HELIX). This team composition implied that the partners in the research project also took on the role of specialist planners in the integrated planning process for the Impulse Project. 


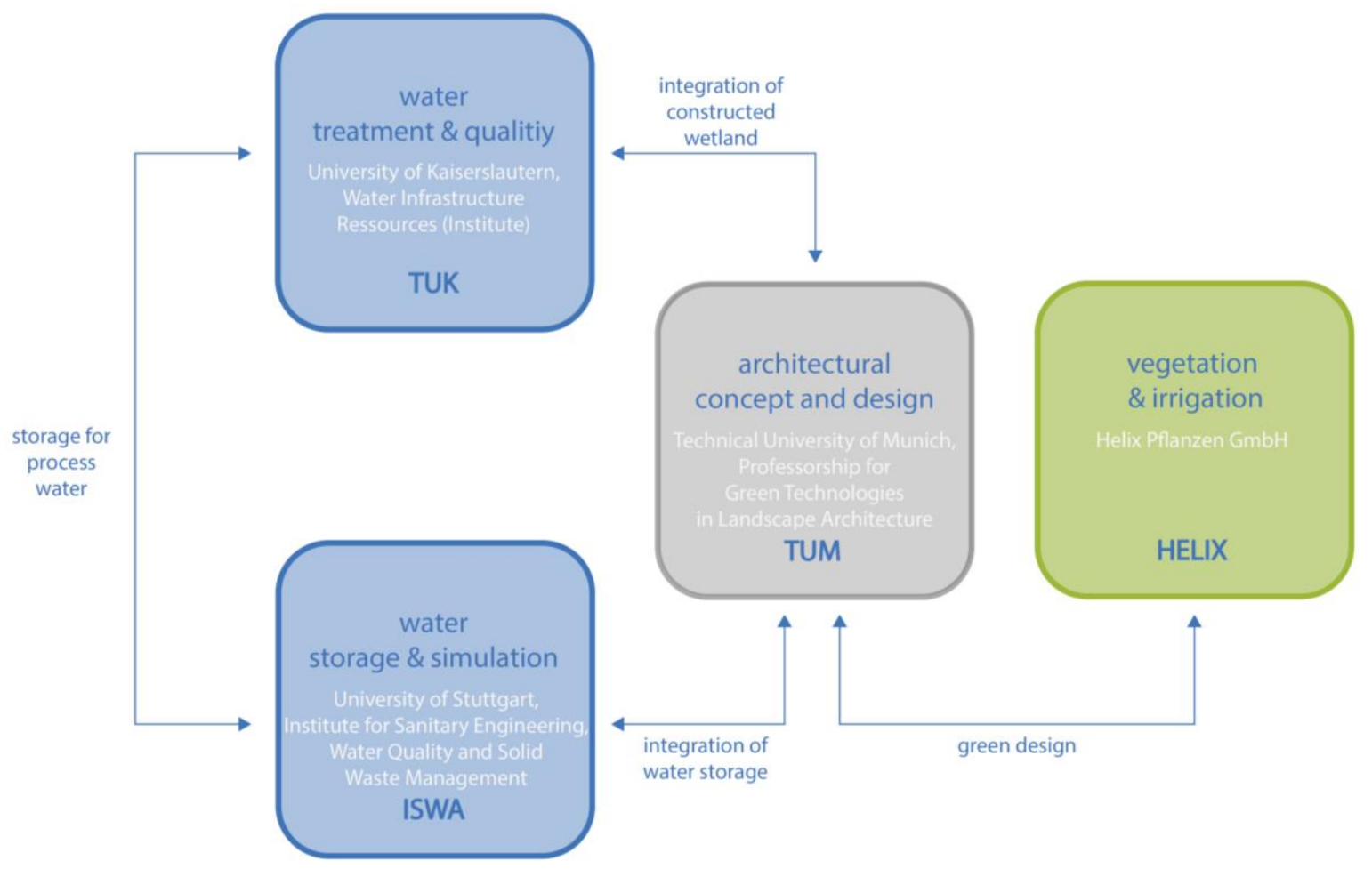

Figure 2. Interdisciplinary planning and research team for the Impulse Project. The interfaces of the design and technical issues are also mapped here.

3.1.4. Specific Objectives, Responsibilities and Contributions of the Project Partners to the Blue-Green System

In an initial meeting, all involved project partners came together and listed their specific goals for the Impulse Project and the related components that they intended to contribute to the blue-green system (Figure 3). The basis for this compilation was, among other things, the approved funds from the research proposal. On behalf of the architectural researchers, the intention was to test the two-sided planning approach as an integrated strategy. The interdisciplinary team's procedure was documented in detail in order to develop it into a design strategy. Even at this early stage, the aim was to use the Impulse Project to positively influence the future development of the neighbouring urban district (Rosenstein quarter). Therefore, publicity was an important aspect too. TUM's area of responsibility included the coordination of the collaboration, as well as the construction site set-up and site management. The planned (overseas) container as a central element (which refers conceptually and design-wise to the Container City) should also be provided by TUM. The researchers from ISWA and TUK are grouped under 'water engineers'. Their objectives relate in particular to the flexibility of the systems, both quantitatively (storage capacity/irrigation with rainwater and grey water, depending on availability) and qualitatively (water treatment). Therefore, the planning and financing of a constructed wetland and all storage tanks (including the cistern) fell within their area of responsibility. This also included water pumps and some control and monitoring components. Helix's main goal was to irrigate vertical greenery with alternative water resources, especially greywater. The horticultural company already has three proven vertical systems on sale, all of which could be used in the Impulse Project. Accordingly, they were responsible for the vegetation, the irrigation technology and, in addition, for the maintenance and upkeep of the greenery. 


\section{ARCHITECTURAL RESEARCHERS}

\begin{tabular}{|c|c|c|}
\hline TUM & $\begin{array}{l}\text { goals } \\
\text { - Application and validation of } \\
\text { blue green strategies } \\
\text { - Testing of interdisciplinary cooperation } \\
\text { - Spatial visualisation of the research topic } \\
\text { - Documentation of planning and } \\
\text { construction process } \\
\text { - Upgrading of the site } \\
\text { - Influence on future planning for neighbouring } \\
\text { building areas } \\
\text { - Use for public relations (pictures, accessibility) }\end{array}$ & $\begin{array}{l}\text { responsibilities and components } \\
\text { - Coordination of the interdisciplinary collaboration } \\
\text { - Integrated design solutions } \\
\text { - Site development } \\
\text { - Logistics and construction management } \\
\text { - (Overseas) container } \\
\text { - Information boards }\end{array}$ \\
\hline
\end{tabular}

\section{WATER ENGINEERS}
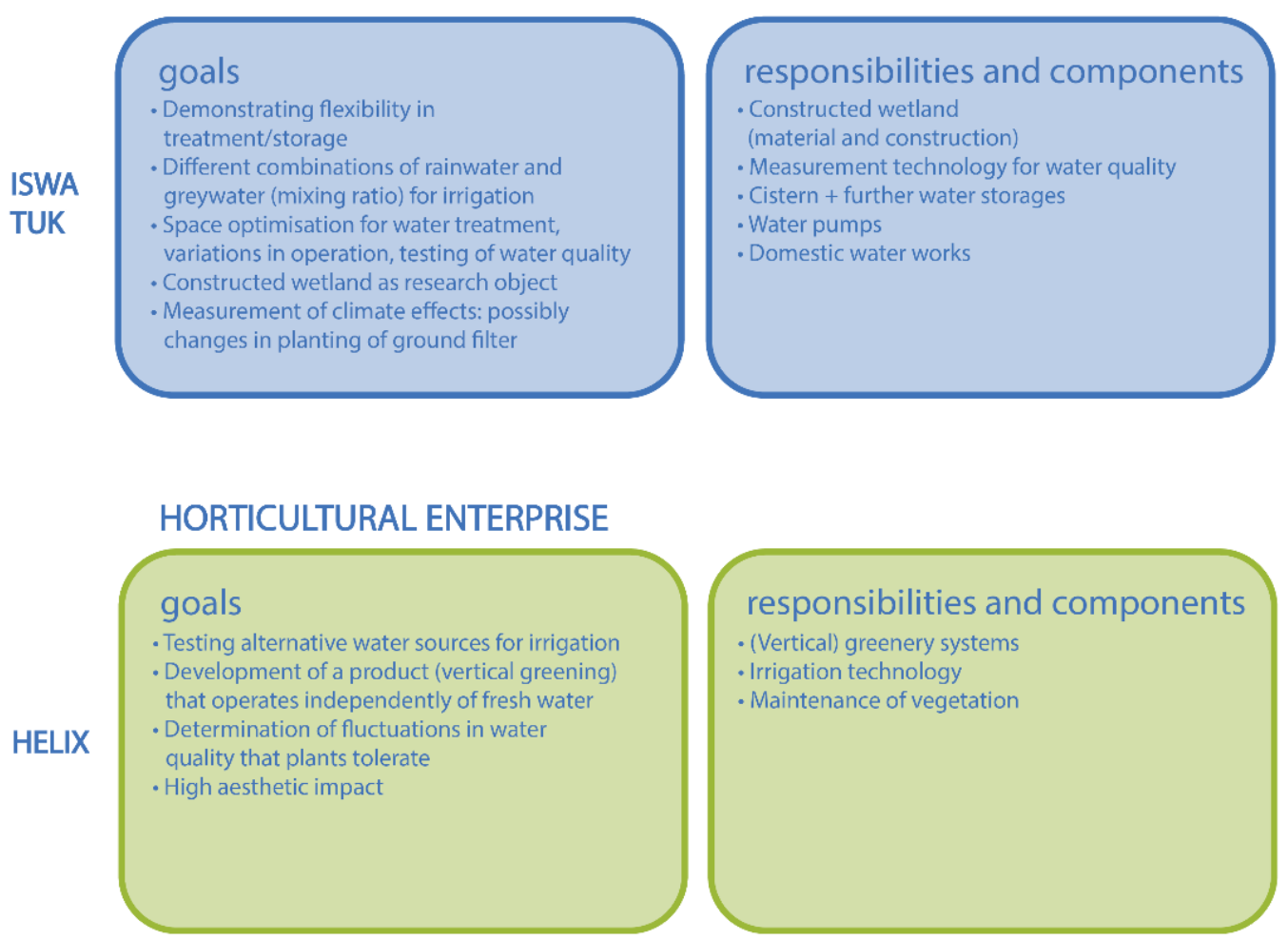

Figure 3. Results of the first interdisciplinary planning meetings: List of specific goals, components and responsibilities of the project partners. Overarching goals that affect the benefits of BGI are not included here.

In this first meeting, the financial framework was also defined. Because the implementation of the Impulse Project was part of a research project, the financial resources were limited by the grants of the funders. At this early stage of planning, the final use of the funds could not be predicted. Therefore, it was not a cost estimate that was made, but a compilation of the available funds. Each project partner contributed a certain budget, which in total made it possible to check the first drafts for feasibility. Some positions were mandatory and fixed, while others contained a margin that should be used to everyone's benefit.

The collection of the components and objectives provided a first overview of the potentials that needed to be developed. In addition, first interfaces and dependencies became visible and conveyed where a precise coordination of the partners would become necessary. The discussions resulted in interrelationships and correlations between the components, which are shown in Figure 4. 


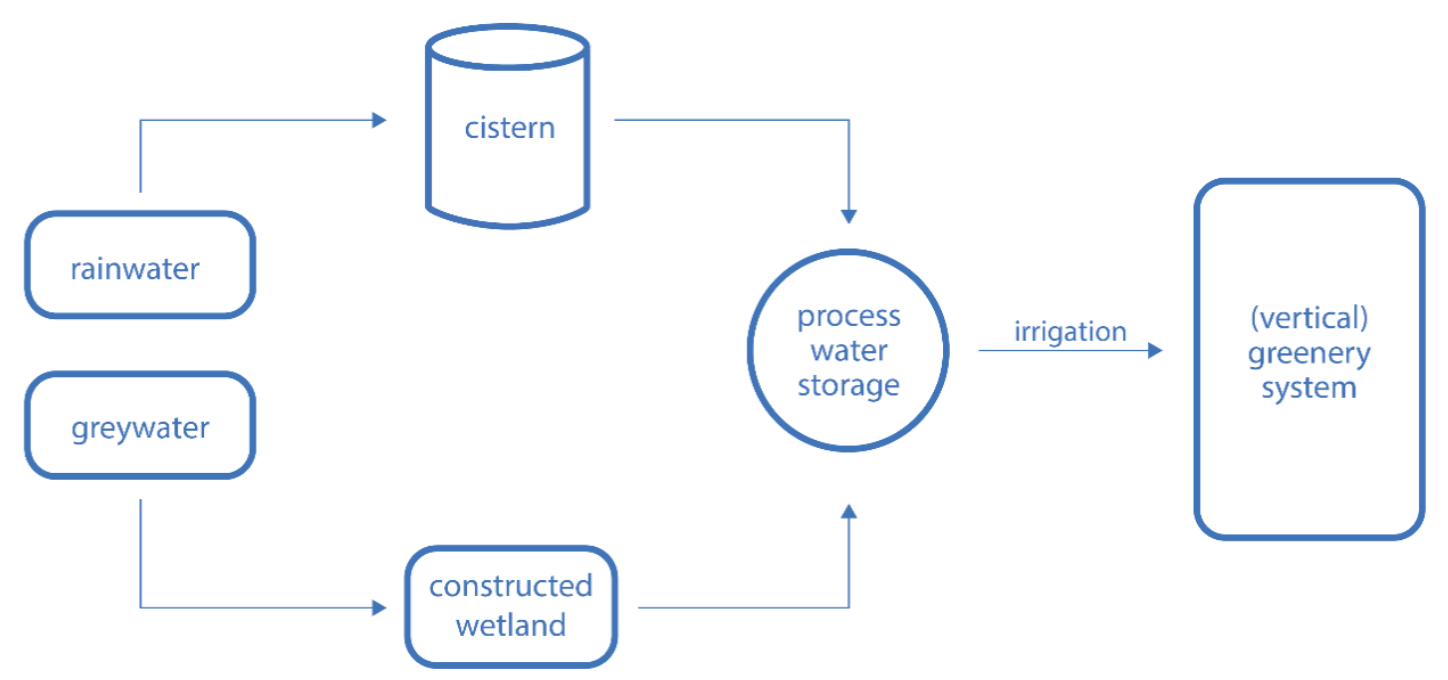

Figure 4. Components at first planning stage of the Impulse Project.

The dimensioning parameters and the conversion into an architectural design were still open at this point in the planning process. Before the spatial issues could be addressed, initial estimations of water availability and water demand were made. A partial roof area of $125 \mathrm{~m}^{2}$ of the residential containers was available for rainwater collection. Precipitation amounts are subject to strong fluctuations, both spatially and temporally. The estimate was therefore based on an average value of the previous five years. From the data of the Stuttgart Mitte weather station in the years 2014-2018, an average precipitation value of $485 \mathrm{~L} / \mathrm{m}^{2}$ per year results, which leads to a total volume of approx. $61 \mathrm{~m}^{3}$ per year [23].

The availability of grey water was also based on estimates and not on measured values. Based on the occupancy data of the residential containers provided by the construction company, a constant presence of 24 persons whose grey water would be available can be assumed. A low average value for grey water from showers and hand basins of 20-40 L per person per day was expected. This value is also subject to unpredictable fluctuations, e.g., fewer persons present over public holidays. Nevertheless, calculations showed that a permanent availability of $320-480 \mathrm{~L}$ per day $\left(115-175 \mathrm{~m}^{3}\right.$ per year) can be safely presumed for treatment in the constructed wetland. The excess grey water should be discharged into the sewer.

In the sense of a two-sided planning approach, a similar calculation was made for the vegetation. The rough target here was to green a total area of $100 \mathrm{~m}^{2}$, preferably with vertical greenery. This quantity was based on the assumption that $100 \mathrm{~m}^{2}$ would be spatially and financially feasible. Three different vertical greenery systems from the company HELIX were considered, all of which rely on artificial irrigation because they do not root into the ground. The need for irrigation is not constant throughout the year and rises sharply in summer. Comparable measured values of built vertical greenery from HELIX were used as a rule of thumb. On an annual basis, this resulted in a total water requirement of $1 \mathrm{~m}^{3}$ per $1 \mathrm{~m}^{2}$ of greenery. This value is also to be considered variable, because depending on the system, a certain drought resistance is given.

This assumption of water availability and water demand was sufficient for further planning. Before the architectural design work began, all fundamentals were collected and contrasted in order to develop a common understanding of the planning task and the disciplines involved: the scientific interests, the specific technical requirements and the desired functions for the users. Subsequently, these points were translated into a spatial problem as a basis for the architectural design. At the same time, the (building) legal conditions had to be evaluated, including liability, accessibility and security. 


\subsubsection{Description of Conflicting Goals}

In the collective planning meetings of all partners, first conflicts of interest became apparent. These were listed without the claim to find an immediate solution. Rather, they served to sharpen the common understanding of the different demands on the project and to underline the need for compromise. The uncertainties and conflicting goals identified at this stage of planning were as follows:

- What criteria are used to select the plants? (Appearance/evaporation performance/ robustness).

- The water should be purified, but not too many nutrients that could serve as fertiliser for the plants should be removed from the water.

- The possibilities and chances of irrigation with untreated grey water had been repeatedly considered. However, this was opposed by concerns about the risk to humans and nature as well as technical objections (e.g., algae formation and clogging of the drip irrigation).

\subsection{Design Phase: Interdisciplinary Planning and Construction Work}

The active design phase started with the handover of the conceptual basis, including all of the complex requirements, to an external architecture office. Parts of the planning activities remained with the architectural researchers of TUM, but the development of the design and the detailed planning were carried out by Daniel Schönle Architecture and Urban Planning. This decision had several reasons: The office of Daniel Schönle is located in Stuttgart and was therefore able to supervise the construction work. Additionally, an architectural office has the necessary equipment and routine for practical building projects. Universities have no infrastructure to manage the execution of construction works. In addition, the office has many years of experience in the design and implementation of green architecture. This transfer of the design to an independent office gave the architectural researchers the opportunity to accompany the process with an external view, and to separate the design components from the academic aspects of integrated blue-green planning. In an iterative process, a total of 16 design variants (V 1-16) were developed, which were repeatedly discussed between the architectural office and the planning participants, as well as the stakeholders involved (inhabitants of the residential containers, artist of the Container City and urban gardening activists). In the following, the emergence and development of the design variants is retraced. The illustration of all design variants would have exceeded the scope of the paper. Therefore, it only contains selected graphics that underline the comprehensibility of the text. The full compilation of all architectural drawings (design variants V 1-16) and further photos can be found in the Supplementary Material (Figures S1-S20).

\subsubsection{Design Variants V 1-10}

On the basis of the determined framework conditions, the architectural office developed first design variants in the areas around the two shortlisted positions (Figure 5 and Figure S9). The comparison of the versions V 1-5 was discussed to identify advantages and disadvantages. The concept sketches varied between several orientations for the container module and presented a range of spatial and functional options. The type of container module(s) had not yet been decided. The idea of refurbishing an old (overseas) container was considered, as well as the customised production of new modules. Both options have in common that the container frame provides the static structure, while the interior can be designed flexibly. 

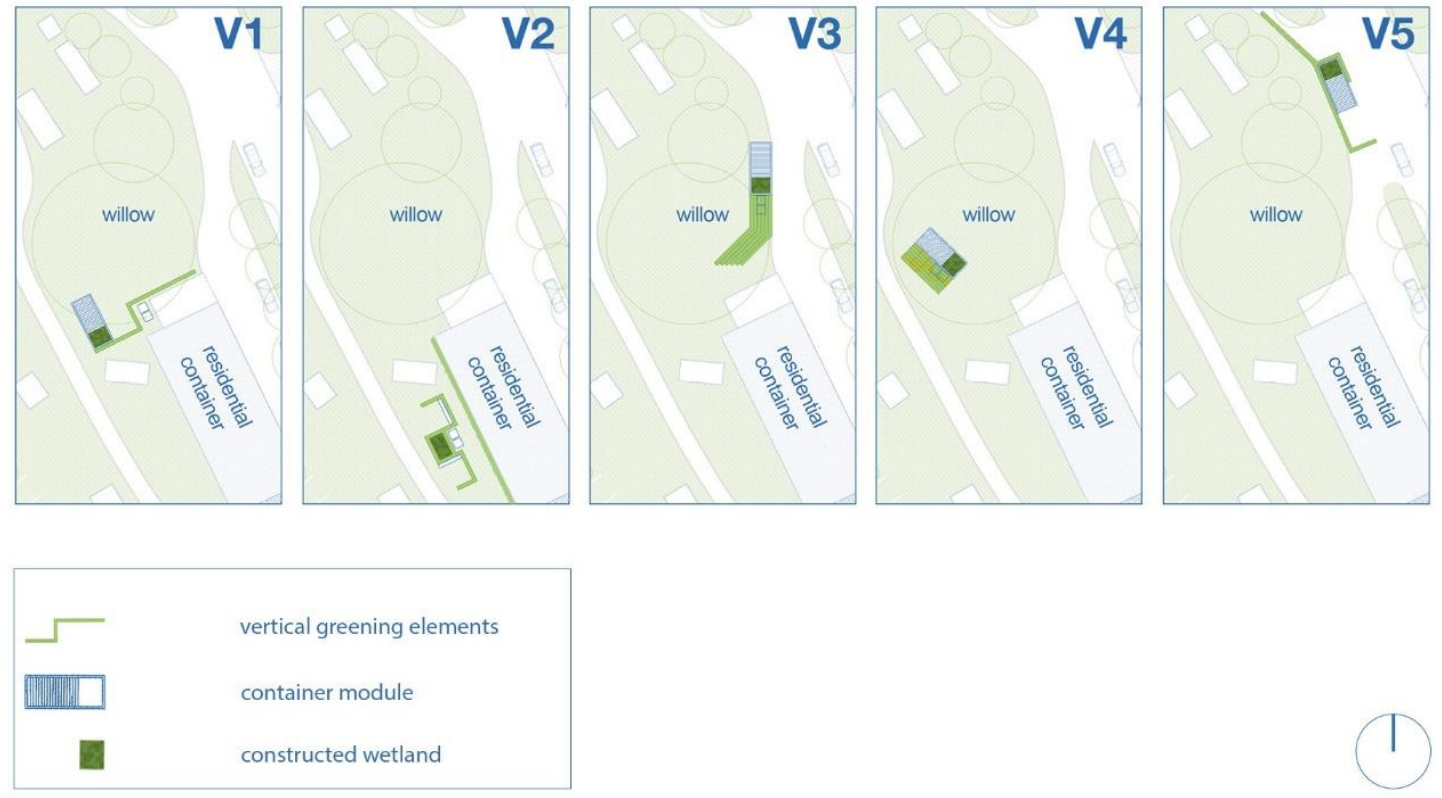

Figure 5. Design variants V 1-5 (no scale), all consisting of one or two container modules, a constructed wetland and various options for vertical green elements. The architect's initial conceptual considerations show a range of options for the planned location and design of the Impulse Project.

A final decision concerning the position as well as the design had not yet been made at this point, as the opinion and expertise of the specialist planners had to be obtained. The following factors were decisive for the further elaboration: Functions and utilisation, accessibility, integration of water storage tanks, environmental conditions for the constructed wetland, space requirements for installation technology, environmental factors, insulation/frost protection, local conditions for greening (humid/dry) and access to willow (see details below). Based on this a further variant V 6 (Figure S10) was developed.

Further consultations were held with the involved parties and the results were incorporated into the continuing design process, V 7-10 (Figures S11-S14). TUM assumed a mediating role between the architectural office, specialist planners and the local stakeholders. This enabled coordinated communication and deliberation of the different requirements before they were incorporated into the spatial design. For example, the large old willow tree at the intermediate area between urban gardening and the residential containers plays a key role for the location, both spatially and socially. The treetop forms a walk-in space, which is used by different groups for smaller events. At the same time, the willow has a protective function as a boundary to the site road, which should not be interrupted. The integration of the willow in the architectural concept had, therefore, been discussed comprehensively with all stakeholders.

All variants (V 1-10) built on the idea of a two-storey container frame solution, consisting of a technical room at the bottom, on which the constructed wetland was placed (Figure 6). Specific planning for the container module did not exist at this stage. A detailed drawing of the two-storey container module was completed at a later stage of the project and is shown in the Supplementary Material (Figure S17). 


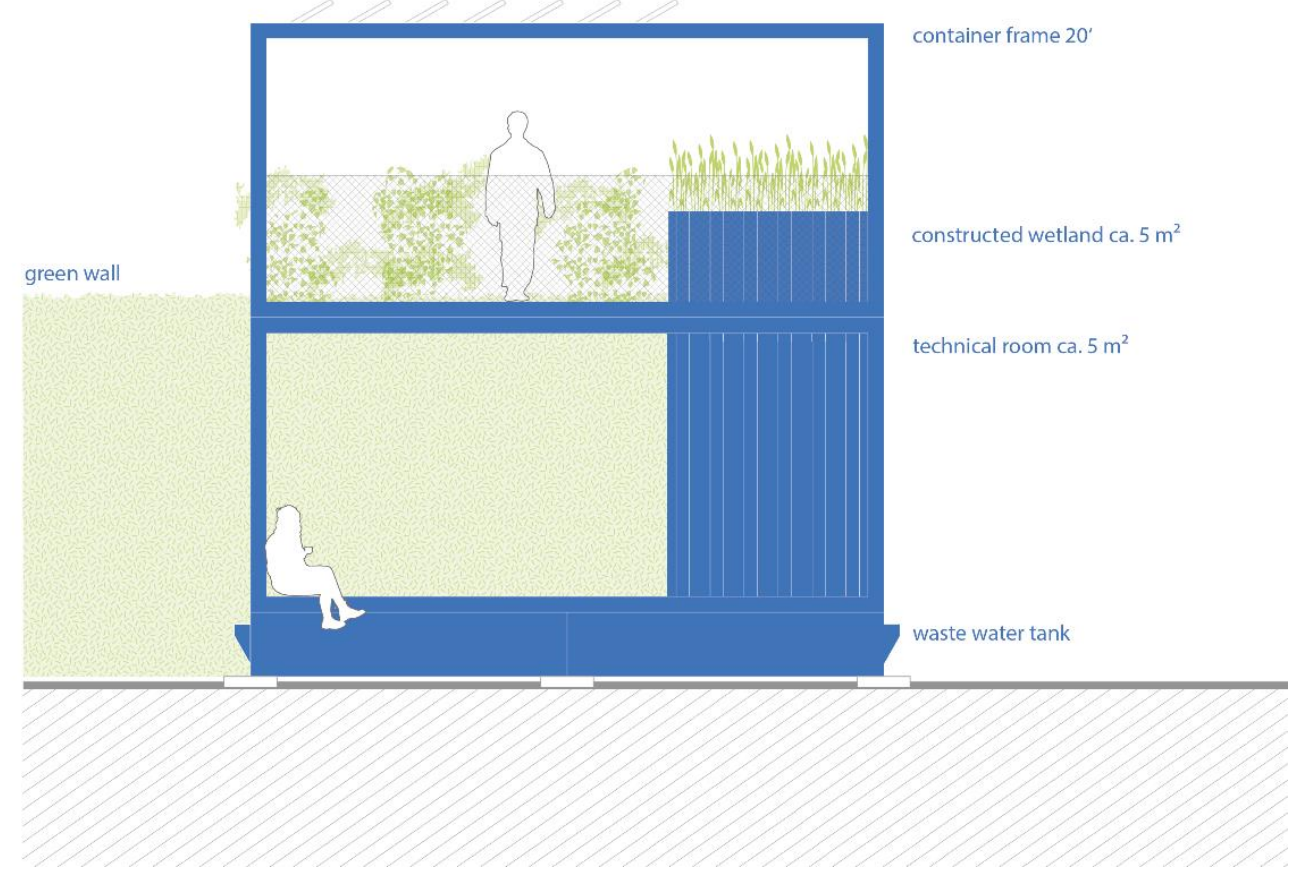

Figure 6. First architectural drawings for a two-storey solution with container frames in the design variants V 1-10 (no scale). The constructed wetland in the second storey would only be accessible with restrictions. The waste water tanks would be integrated into the overall concept as a base.

\subsubsection{Design Variants V 11-13}

As the planning progressed, the final decision regarding the location of the container frames needed to be made. At a meeting of all project partners, the variants V 11-13 (Figure 8 and Figure S15) were presented for discussion. V 11 once again showed the original favourite: a prominent position at the entrance of the Container City that had a high potential for a large public impact (location (1) in Figure 7). In the meantime, however, it had become clear that the dust blown from a neighbouring cement plant could damage the constructed wetland. In addition, the directly adjacent site road with heavy traffic would significantly reduce the sojourn quality. The site was also rather shaded, which did not allow effective cooling by irrigated vegetation; this was in contrast to the aim of the research question. The function of the constructed wetland would also be reduced if the solar radiation was too low. The proposed site was therefore moved to the second shortlisted position, the quieter and sunnier area between the urban gardening and the construction workers' residential containers. In the design variants V 12 and V 13, the Impulse Project was positioned in this area. All partners agreed with this location as the final position (location (2) in Figure 7). 


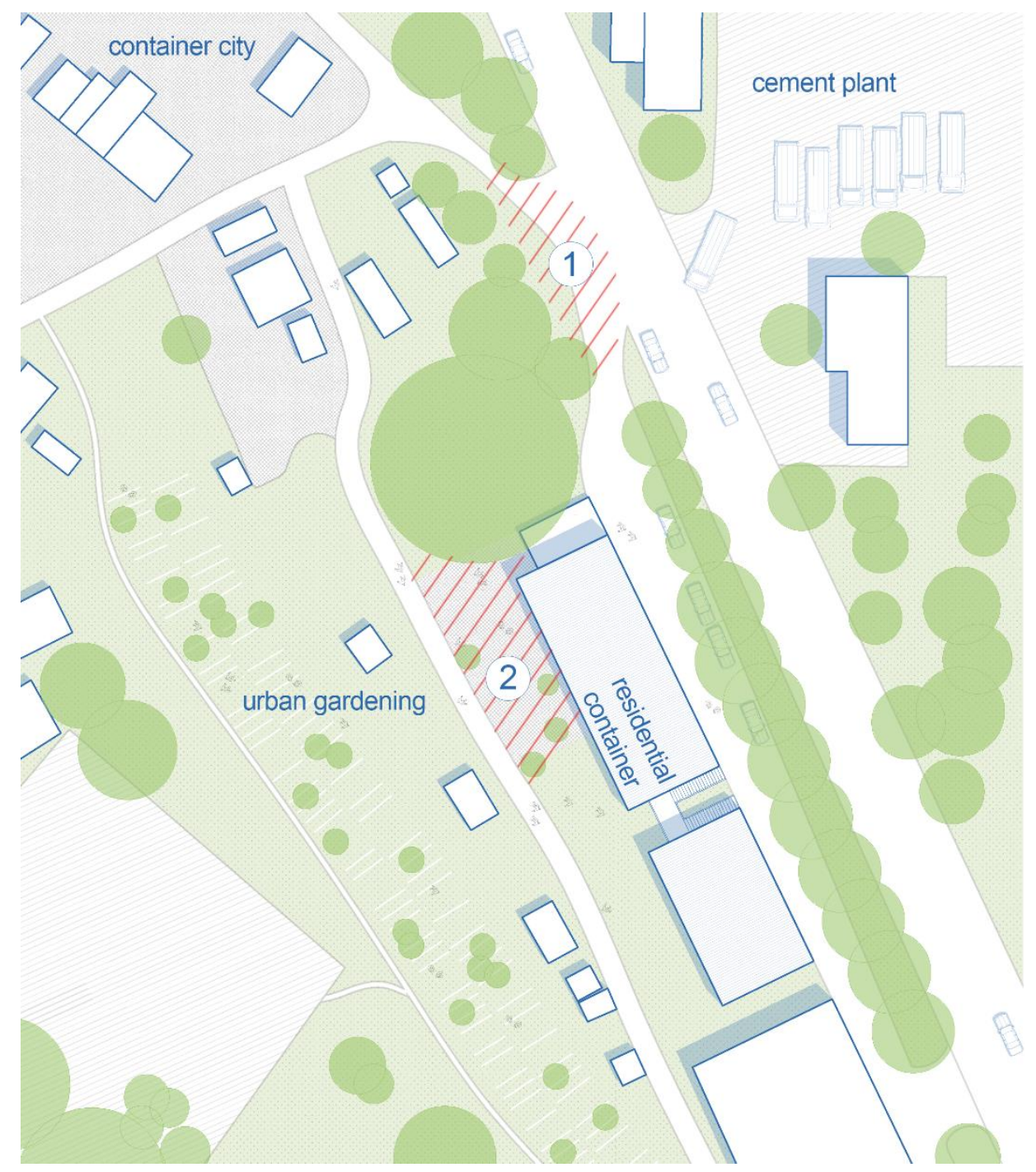

Figure 7. Site plan with location options (no scale). (1) Initially favoured position at the entrance to the Container City. (2) Final location between residential containers and urban gardening.

With regard to the components of the Impulse Project, space-defining factors were also identified and discussed at the planning meeting. The tanks required for grey water and rainwater storage became decisive space-creating elements due to their volume. The size and design of the tanks were not fixed at this time. It was decided that their realisation should take place aboveground in order to keep the whole project mobile and to make all components experienceable in terms of didactics. For rainwater, a cistern with a capacity of $11 \mathrm{~m}^{3}$ was intended. The cistern was intended to be equipped with built-in techniques for retention with throttled discharge (compare Section 3.1.2), which could not be transferred to "simple" storage solutions, such as a number of standardised plastic tanks (IBC). Thus, the original idea of giving the rainwater storage tank a different shape so as to integrate it into the container solution had to be rejected. Instead, a reinforced concrete cistern was established as an integral part of the system and design concept.

The storage of raw grey water and process water turned out to be more flexible in terms of design and not restricted to one product. Because grey water is a continuous source of water, fluctuations have to be only slightly intercepted and balanced. Therefore, the storage tanks were designed to be smaller than the rainwater storage tanks. Various volumes and possibilities for integration into the overall system were considered.

Further, the constructed wetland had to be integrated into the design concept. There was no reference for such a compact and mobile constructed wetland, so many questions of 
operation and requirements had to be discussed with the engineers from TU Kaiserslautern (TUK). The vertical flow constructed wetland is typically filled with sand and gravel and planted with reeds. With a surface area of $4-5 \mathrm{~m}^{2}$, it results in an expected weight of 10 tons. A two-chamber system was to be realised in order to investigate the filter effect of different substrates. Based on the performance of other filters, it has been estimated that a constructed wetland of such a dimension could treat 400 to $500 \mathrm{~L}$ of grey water per day. The exact capacity can only be determined during operation. As already described, the presented design intended to place the constructed wetland in a container frame on the second storey. The architects' idea of distributing the soil volume, and thus the mass of the constructed wetland over a larger area with a lower installation height, was rejected by the specialist planners. The substrate height of ca. $1.5 \mathrm{~m}$ had to be retained to ensure the cleaning performance of the filter. An advantage of the elevated position of the filter was the high solar radiation as this has a significant influence on the filtration effect. In terms of safety, the accessibility of the filter had to be considered. Since it is a waste water treatment system, no unauthorised persons should have access to the filter in order to avoid any health hazard. With this in mind, the two-storey solution was pursued, in which the constructed wetland was placed on the roof of the technical room where the access could be regulated by the staircase (Figure 6).

\subsubsection{Integration of Technical and Nature-Based Systems into the Architectural Design}

In order to be able to make progress in the planning process, numerous detailed questions brought forth by the architectural office had to be discussed with the specialised engineers. The following points came up:

- Required space for equipment in the technical room: the partners' installations as specific products, including dimensions and electrical power, had to be listed in order to dimension the room adequately.

- Integration of wastewater tank: the spatial, functional and design integration of the tanks and the necessary requirements were specified.

- Insulation/frost protection of cistern: the question of frost resistance of the cistern was discussed with the manufacturer. The cistern was not provided with extra insulation but embedding the cistern half a meter into the ground was considered sufficient to prevent it from freezing in winter.

- Weight of the constructed wetland: this turned out as a highly relevant parameter with regard to the statics of the container frames and transportability of the project. The weight varies depending on the level of moisture penetration.

- Function of the container frame: ideas and concepts were collected and developed for the use of the container frame as a (semi) public open space, e.g., as a stage or for public events.

- Design modular vs. integrated: in terms of design, it was considered to what extent an integrated overall concept or a visibly modular composition of the individual parts should be realised.

- Didactic approach: the Impulse Project aims to inform future visitors about blue-green infrastructure and integrated design. For this reason, the planning took into account possibilities of knowledge transfer and visualisation of the functioning (e. g., water flows).

The design variant $\mathrm{V} 13$ formed the basis for further discussion with the specialist planners. The container module with the top-mounted constructed wetland was located south of the willow. This variant entails that parts of the vertical green elements are attached to the residential containers as building greening. In this variant, the cistern and the grey water storage tanks are individually placed next to the container, and thus serve to visualise the water flows (Figure 8). 


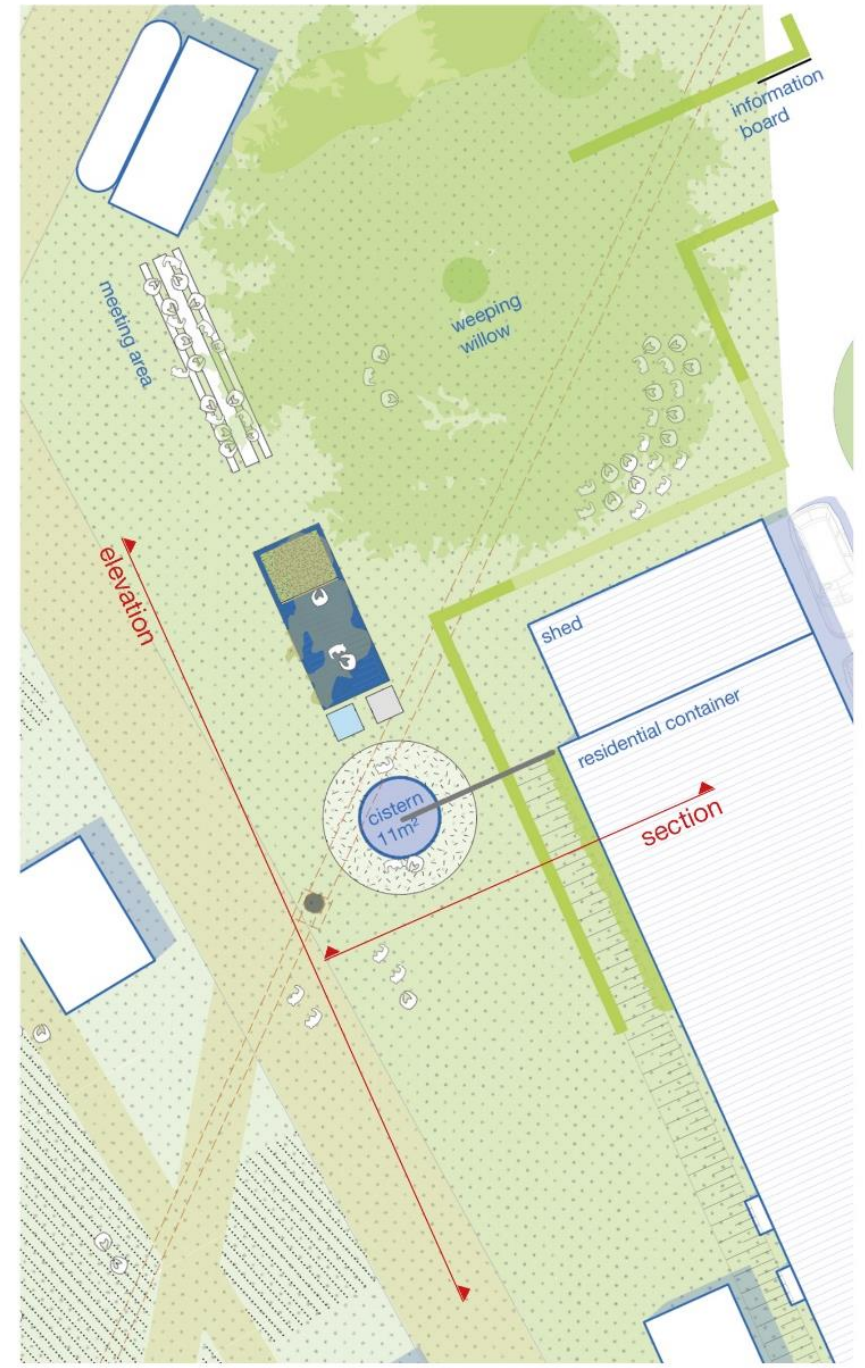

(a)

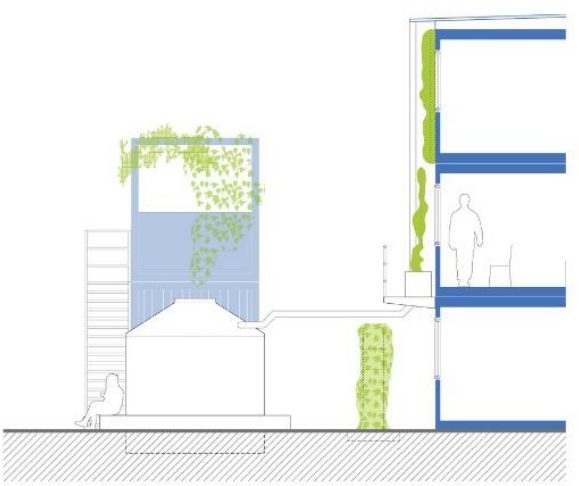

(b)

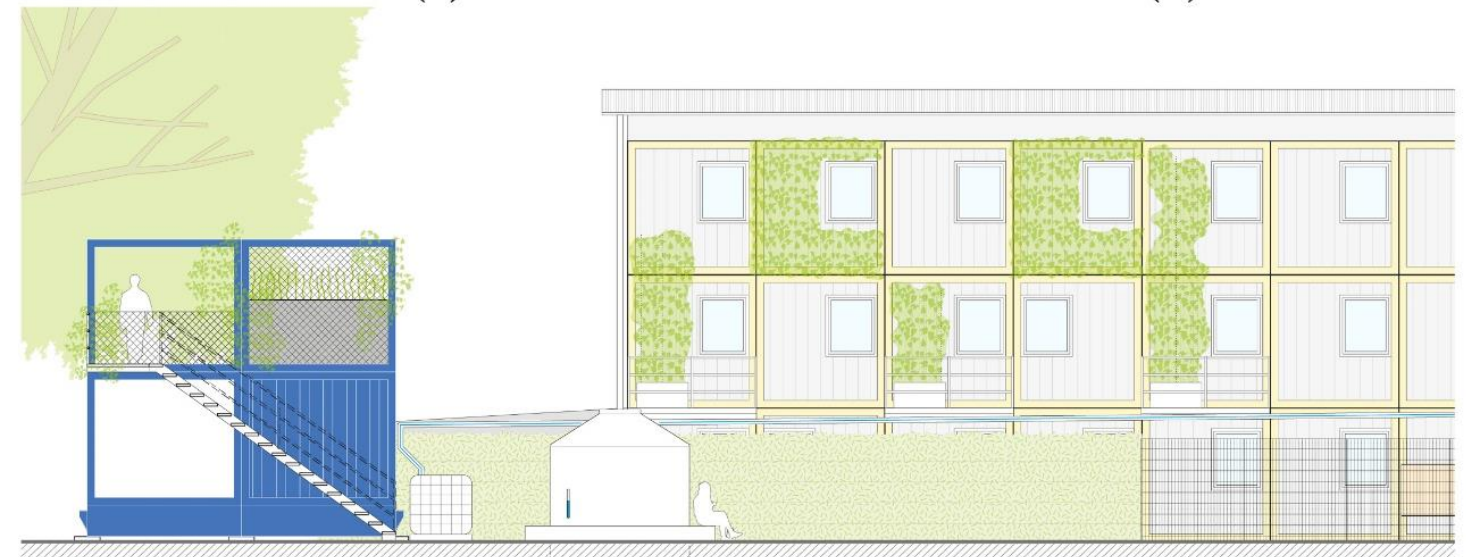

(c)

Figure 8. Design Variant V 13 (no scale) as a basis for discussion and elaboration with the specialist planners: (a) site plan; (b) section through residential container and façade greening; (c) elevation of two-storey container module, cistern and facade greening.

The dialogue with the specialist planners revealed weak points in the planning and made it possible to evaluate the project's feasibility. The direct neighbours were also 
involved in the discussion in order to reduce reservations and to clarify any questions. This communication strategy in the design process enabled all perspectives to be taken into account as well as strengthened the concept.

\subsubsection{Budget Constraints and Integrated Solutions}

As in all implementation projects, the feasibility of the architectural design was directly dependent on the construction costs and the available budget. The listing of all components conveyed which items had not been previously calculated by the project partners. For example, the responsibility for grey water tanks and flow meters had to be clarified. These are objects that were of interest to several participants because they are located at the interface of storage, treatment and irrigation.

Furthermore, it turned out that the planned architectural adaptations of the overseas container, as well as the integration of the manifold technical components and requirements, posed a high constructive and, thus, also financial effort. Therefore, the original idea of using a discarded container was dismissed and a specialist company was commissioned to manufacture a container in accordance with the requirements for the project. This solution, which was initially more expensive, allowed the direct integration of parts of the electrical installation, as well as the trough for the constructed wetland. This solution was only possible through close cooperation within the planning team because it required flexibility beyond disciplinary budget limits. The joint integrated solution bundles advantages and creates synergies, which, due to the costs saved elsewhere, makes an overall better solution possible.

A closer look at the costs for the vertical green systems revealed that their costs were significantly higher than the originally assumed values. High material costs and the expenditure for pre-cultivation were cost drivers. The planned green systems with approximately $100-120 \mathrm{~m}^{2}$ surface area had to be reduced by half. The dimensioning of the cistern and constructed wetland remained the same (due to research interest and corresponding needs of measurements of the water engineers) and with it, the available water quantity. Application options for the resulting water surplus were developed later in the planning stage.

\subsubsection{Design Variants V 14-15 and Final Design V 16}

The two-storey design of the container module turned out to be a significant problem. As described above, it was not possible to achieve a better load distribution on the roof by flattening the filter trough. In addition, the privacy of the adjacent residents would be disturbed by the two-storey-solution, as the height allows for a direct view into the living/sleeping rooms. Therefore, a one-storey solution was developed, which offered great potential for saving construction costs (statics, no stairs) and spatial advantages, such as better visibility of the constructed wetland for visitors (Figure S18). This adaption of the design also contributed to the intended goal of creating a mobile, temporary architecture. A technical disadvantage of this solution is the change of the hydraulic section of the constructed wetland. It is no longer possible to regulate the drain of the filter by gravity. Instead, additional pumps have to be installed.

In the final design variant $\mathrm{V} 16$, the core element of the project is formed by two container frames, which are placed next to each other, but offset by half the container length. (Figures 9 and 10). The first container hosts the constructed wetland and the technical room. The second one contains storage tanks for raw grey water and purified grey water. The four tanks $(2 \times$ raw grey water, $2 \times$ filtered grey water $)$ were clad with wooden decks in such a way that two terraces on two levels were created, which are available to visitors as a meeting area (Figures S3 and S8). In the technical room, another tank exists where rainwater and grey water are mixed for irrigation. The central control of all pumps, valves and sensors is also installed there. The pipes (electricity and water) that lead to the cistern and the overflow pipes into the sewer are installed underground. 


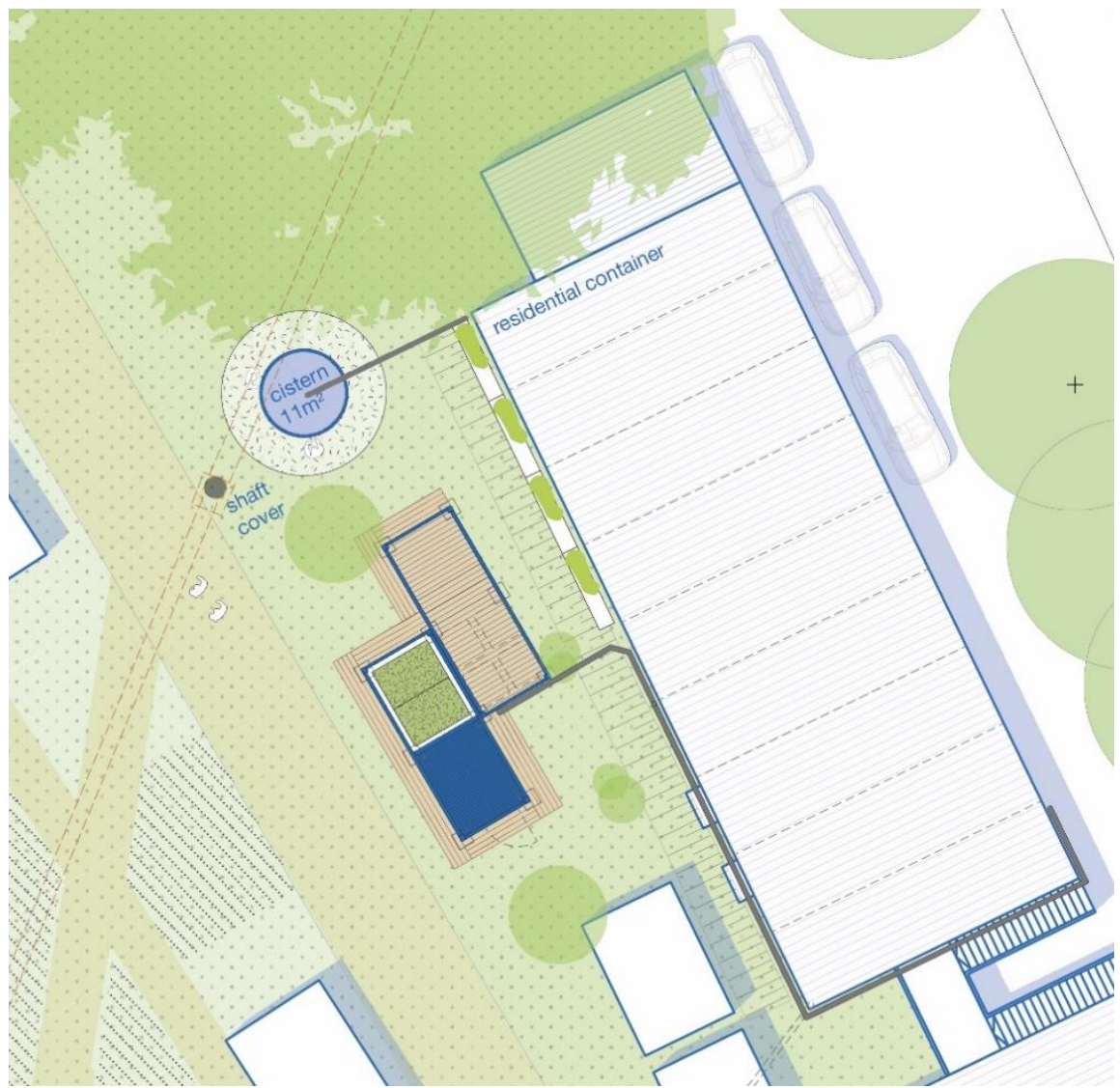

Figure 9. Final design variant V 16 (no scale). The single-storey solution consists of two container frames housing the technical room, the constructed wetland and two terraces, of which one is on top of the grey water storage tanks.

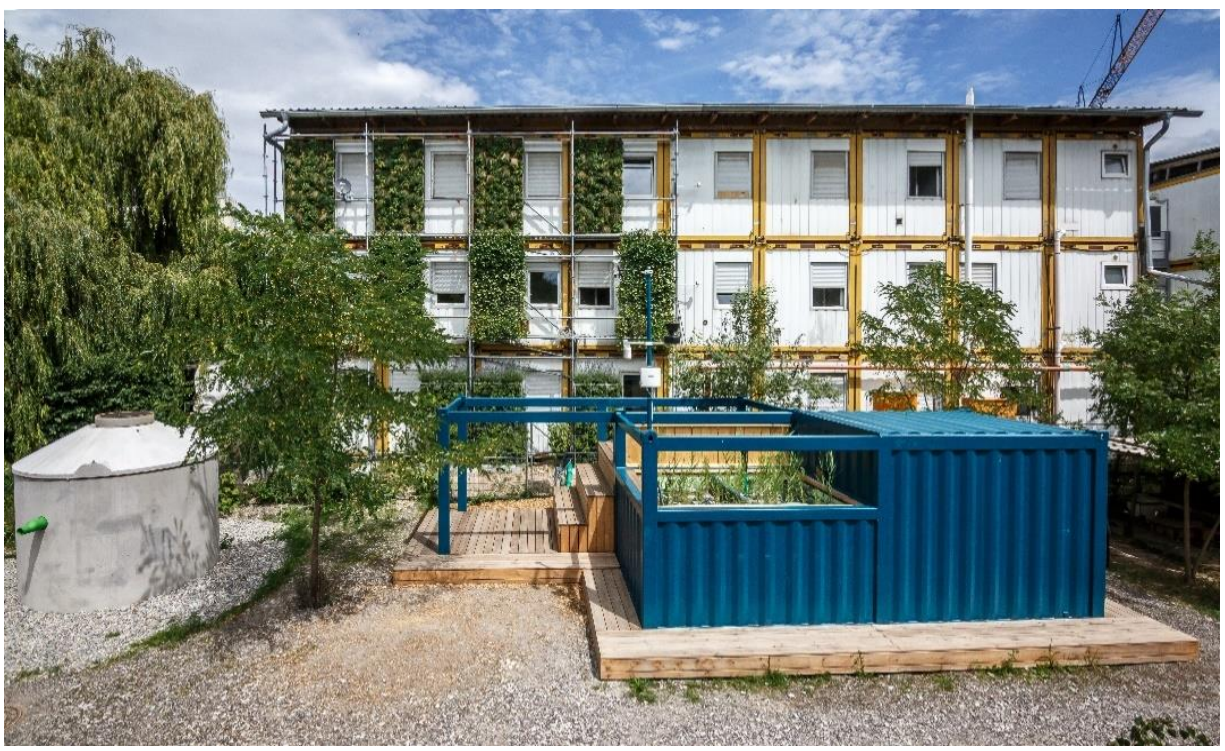

Figure 10. The Impulse Project in built state. On the left: retention cistern made of reinforced concrete with throttled emergency overflow. On the right: two container frames with integrated constructed wetland. In the background: façade greening on residential containers. Rainwater is directed from the roof into the cistern. Grey water is available from the sanitary containers (far right in the picture). Photo: Julian Rettig. 
As described above, the amount of vertical greening had to be reduced for cost reasons and, therefore, a larger amount of water than necessary is available for irrigation. It was foreseeable that more water would be available than was needed to irrigate the vertical greening. This resulted in several ideas for its use: infiltration/evaporation on site, transfer to the urban gardening initiative, filling of mobile watering carts for urban greenery. All variants referred to open systems and were therefore dependent on the hygienic safety of the treated grey water. They should, therefore, only be specified after the examination of the process water in order to prevent any health hazard.

The reduction of the amount of green elements also called for a new design concept. The decision was made to focus on facade greening. This resulted in a clear and coherent design solution and offered the most microclimatic advantages, as the inhabitants of the residential containers benefit directly from cooling through evaporation and shading. Three vertical systems were chosen, which differ in their requirements and characteristics. In order to provide mobility, scaffolding was erected directly in front of the façade to serve as a supporting structure for the greening of the upper floors (Figure 11 and Figure S5). On the ground floor, free-standing elements (Helix Elementa ${ }^{\circledR}$, Kornwestheim, Germany) were installed front of the containers where pavement slabs serve as a simple foundation. These modules consist of wire baskets with a depth of $40 \mathrm{~cm}$. They are filled with substrate and planted with various plants (ivy, lavender, geranium, bluebeard). In the middle level, a combination of planters and trellises planted with climbing plants (ivy, clematis) were installed (Helix Elata ${ }^{\circledR}$, Kornwestheim, Germany). The upper level was realised with a 'vertical garden' system (Helix Biomura ${ }^{\circledR}$, Kornwestheim, Germany). These are soilless modules, planted with a variety of grasses and flowering plants (spring cinquefoil, sea thrift, dianthus, lady's mantle, evergreen candytuft, tufted fescue). All three systems have different advantages and disadvantages in terms of evaporation capacity, shading and resilience. The requirements for quantity and frequency of irrigation also differ. These aspects will be examined in the operational phase.

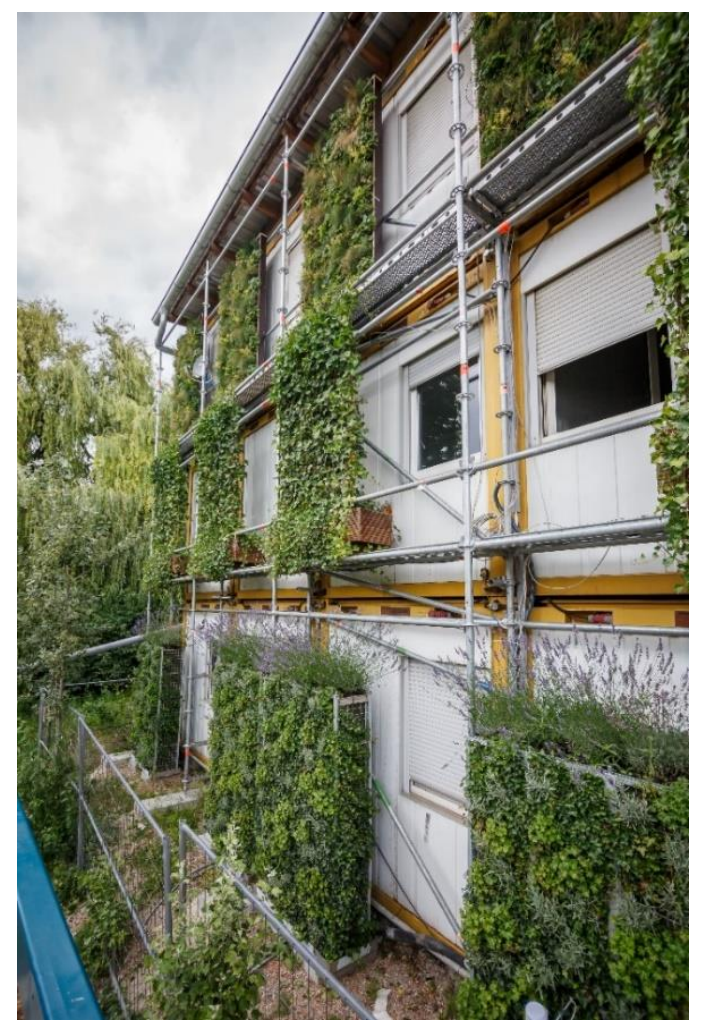

Figure 11. Three different systems of vertical greening were installed to investigate differences in performance. A scaffolding supports the plant boxes of the upper floors. Photo: Julian Rettig. 


\subsubsection{System Design and Flow Chart}

Figure 12 shows the flow chart that emerged out of this interative planning process: The cistern is connected to the rainwater pipe of the residential containers. $7 \mathrm{~m}^{3}$ of the cistern are available as permanent storage. A further $4 \mathrm{~m}^{3}$ are used for retention and in the event of heavy rainfall, the discharge is throttled. This effluent is infiltrated directly on site, and thus serves to recharge the groundwater. The cistern is equipped with a pump and a level gauge. The grey water from the showers and hand basins flows directly into the grey water tanks via an open-channel pipe. Since more grey water regularly accumulates than can be treated, there is a direct overflow into the sewage system. The reservoirs for untreated grey water consist of two interconnected $1 \mathrm{~m}^{3}$ intermediate bulk containers (IBC). From these tanks, the water is pumped into the two chambers of the constructed wetland and spread over the entire surface. The chambers are filled with different filter substrate to detect differences in the filtering effect. The constructed wetland is insulated so that it does not freeze in the winter. Frost would destroy the micro-organisms that provide the cleaning performance. Each chamber has a submersible pump installed at the bottom of a wide pipe. The purified water flows through small openings into this pump sump and is pumped from there into two interconnected $1 \mathrm{~m}^{3}$ IBC storage tanks. These reservoirs are equipped with UV lamps for the hygienic purposes of killing bacteria, viruses, fungi, etc., and preventing them from multiplying in the water.

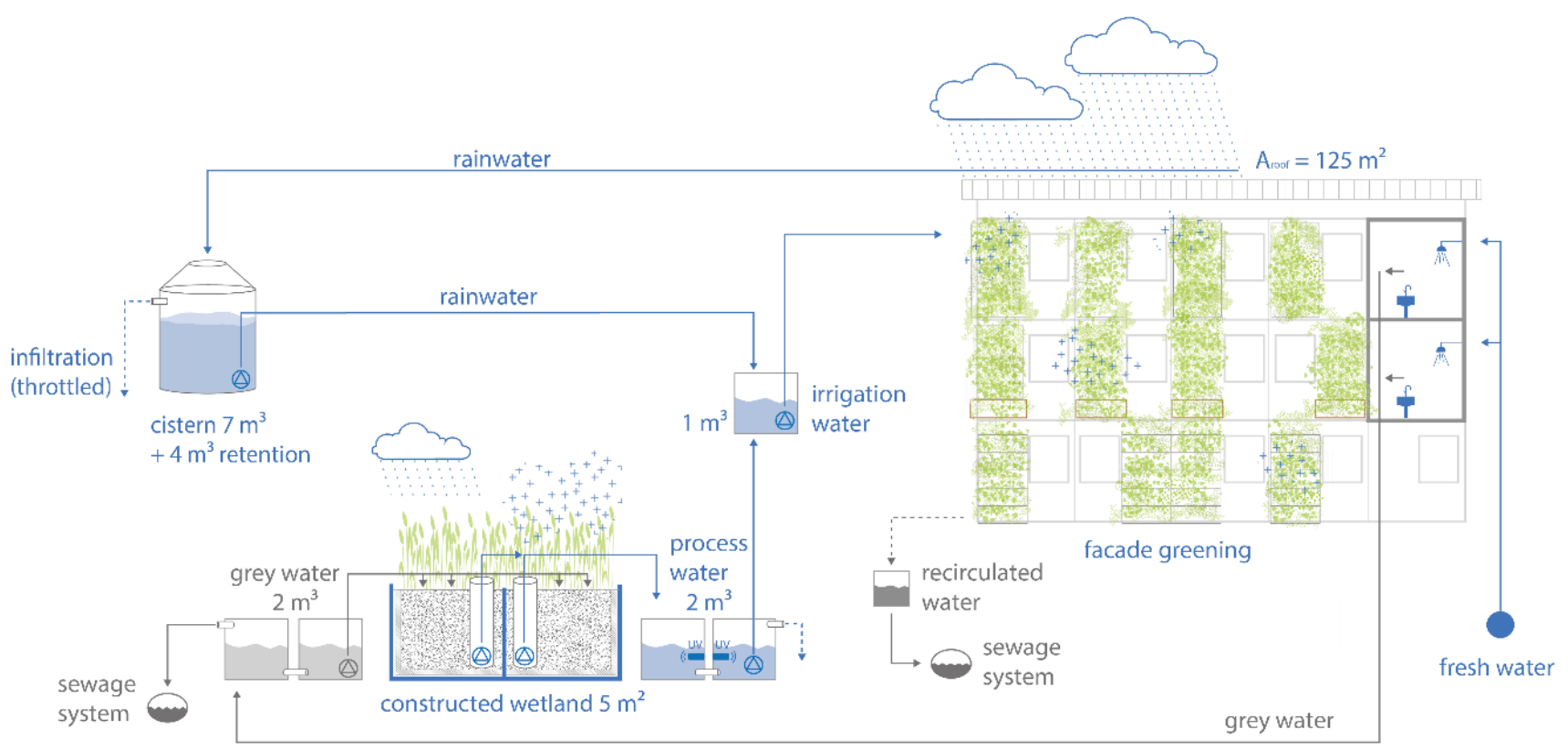

Figure 12. Flow chart Impulse Project: The technical components of the system and their connections are shown here. The drawing is not to scale.

The mixing $1 \mathrm{~m}^{3}$ water tank, from which the irrigation system is fed, is located in the technical room. It can be filled with rainwater and/or process water depending on demand and availability. Irrigation is carried out as drip irrigation for all three green systems. The excess water of all vertical elements is collected and measured. This allows the actual water consumption and the resulting evaporation capacity to be determined.

\subsection{Post-Design Phase: Transfer to a Design Strategy}

Following Roggema's description, the third phase consists of reflecting and communicating the results of the first two phases. The findings are to be made available to the wider public and discussed (academically) [20]. In case of the Impulse Project, this results in two main activities: The use of the built object for visiting and knowledge transfer, as well as the transfer of the experiences gained in the planning process into a design strategy. 
Due to this two-way approach, the urban public and the academic community are equally addressed. Since this paper is directed at the professional public, the events and activities at the Impulse Project will not be described in further detail below. Instead, the focus remains on the design strategy (Figure 13). Nevertheless, the on-site experience is an elementary part of the concept and a site visit is recommended to all interested.

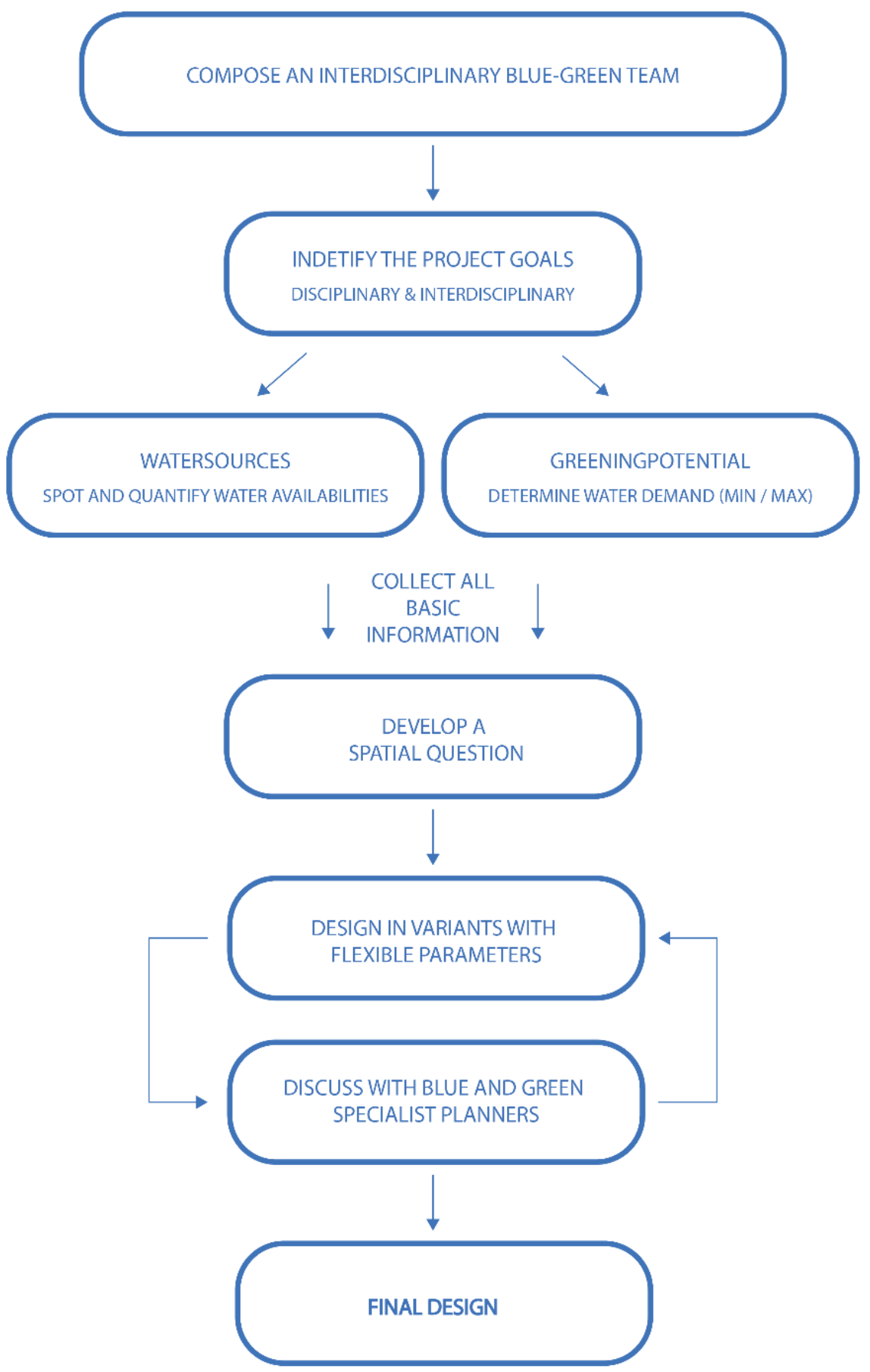

Figure 13. Design strategy for integrated blue-green architecture projects.

The design strategy describes the procedure for a blue-green project step by step and serves as a guide for architects, landscape architects and engineers to coordinate the planning in an interdisciplinary team. The procedure is based on the experiences from the Impulse Project and has been abstracted and generalised accordingly. In its application, the design strategy focuses on the Central European region, respectively on temperate climate 
zones. The transferability to other climatic and socio-cultural contexts must be examined in each individual case. The work steps presented below are intended to ensure that blue and green objectives are equally taken into account and lead to a synergetic overall solution.

The experience at the Impulse Project has shown that the composition of the interdisciplinary team is crucial for successful integrated planning. Thus, the composition of the planning team is the first step in the process. The exact composition of the team may vary depending on the project, but it should be ensured that the integrating function is taken over by one of the participants. Three possible team compositions are described in more detail below:

1. (Landscape) architect + water engineer. The (landscape) architect is responsible for planning the vegetation and developing the overall spatial concept. He/she also forms the integrative authority and incorporates the analyses, recommendations and objectives of the water engineers into the concept. In this case, the (landscape) architect should have experience with integrated planning in order to implement the "blue" parts in the best possible way. If the architect assumes the integrating function, a landscape architect or specialist for green planning should be included in the team who is responsible for the use of plants and irrigation requirements. This constellation corresponds to the planning team of the Impulse Project.

2. Architect + specialist planners (blue/green) + external consultant. An interdisciplinary team is assembled, in which all functions are represented. The coordination of the integrated planning is carried out by an external consultant with competence in blue-green projects.

3. (Landscape) architecture office with all planning participants in-house. The commissioning of a large planning office, which covers all blue and green sections and can, therefore, carry out the integrated planning on its own, is also a possibility. In this case, the interdisciplinary cooperation takes place in-house. An example of such a company would be Ramboll Studio Dreiseitl, which has already successfully conceptualised, designed, engineered and implemented large-scale blue-green projects.

Once the team has been assembled, it is important to define the disciplinary and interdisciplinary goals. The first planning meetings can be used to identify contradictions and conflicting goals. This promotes a common understanding of the planning task.

In the next step, the necessary fundamentals are recorded. Water sources and greening potential are identified in order to make initial quantified assessments. These investigations are necessary in order to make an assessment of the site-specific problems. This will reveal how the project can contribute to goals, such as water sensitivity, climate resilience, urban climate, etc. Ideally, water availability and water demand are specified in ranges from minimum to maximum to also reflect the available scope. The water sources that are available for a specific project must be checked separately for quantity and quality. Possible sources are, for example, precipitation water, grey water, under certain conditions ground water, water from production processes, condensation water from technical installations or air conditioning systems and surface water. The accessibility of water resources varies significantly and must be taken into account. Necessities for storage and treatment must also be examined by the water engineers. The potential for greening depends on the type of building project on which the blue-green design is based. In principle, the potential for greenery in new buildings is greater than in existing buildings in terms of the integration of climate effective greenery. New buildings enable the implementation of innovative systems that can be specified in terms of water availability. For projects with existing green structures, these should be comprehensively recorded and evaluated in order to determine irrigation requirements. The options for greening potential range from building greening (roof/façade) and open space to urban greenery.

The analysis of the blue and green potentials is incorporated into a compilation of basic information (Figure 13). Based on this data collection, the spatial question that forms the basis of the design for the project is developed. This step of the design strategy may appear delayed or self-explanatory at this point. In fact, it is a central moment in the 
process and the sequential order described here is indispensable. For any project that aims to combine vegetative elements with comprehensive water management, the data basis must first be created in order to recognise the potential of the site. By translating this into a spatial issue, the possibility emerges to start a creative process which takes all blue and green aspects into account. It is not the aim to find a purely technically optimised solution, but to develop spatial qualities in the sense of (landscape) architectural design.

The spatial question forms the starting point for the design activity of the (landscape) architect. Several variants that can be compared should be drafted in the process. This approach enables the consideration of flexible parameters. Fluctuations in water availability (especially rainfall), seasonal changes and vegetation growth processes influence the bluegreen correlation. In addition, many technical details are still open at an early stage of the conceptual design, and these can also be specified by using variants. In iterative phases, the design variants are discussed with the specialist planners in order to incorporate disciplinary knowledge and insights into the overall process. How many of these loops are passed through depends on the project.

At the end, the final design emerges, which takes into account all blue and green components, creates a synergetic relationship and is ready for implementation.

\section{Discussion and Conclusions}

This study is based on the question of what an integrated planning process for bluegreen architecture can look like and what insights can be gained for future planning. The documentation of the interdisciplinary planning for the Impulse Project demonstrates how such a planning process works in practice, which problems arise and where opportunities for synergies and integrated solutions lie. The coordination of the specific objectives resulting from the different perspectives of the involved planners can enable a holistic approach that leads to multifunctional solutions. Blue-green architecture designed according to these principles can allow for the synergetic merging of disciplinary objectives. These include, for example, improving the microclimate, stormwater management, environmental education and sojourn quality.

However, the exemplary design process of the Impulse Project is not able to represent all the parameters that might be considered regarding blue-green architecture. The scale and character of the project does not allow to incorporate all possible blue-green solutions, and there are far more elements available than are shown here. Existing greenery, green roofs, open water areas and many other components of blue-green infrastructure, as well as other alternative water resources, have not been considered in this study. In this regard, please refer to the overview of blue-green systems given by, e.g., Winker et al. [24] and Pötz and Bleuzé [25].

Furthermore, the integration into a larger network of blue-green solutions could only be considered to a limited extent in the Impulse Project. Water flows, in particular, are part of infrastructural constructions that are not constrained by building and property boundaries. Accordingly, it is desirable to consider them across quarters. Water treatment, water storage and retention areas are more efficient and economical on a larger scale [11,26,27]. Green roofs also become more economically and ecologically cost-effective in terms of rainwater management if they are implemented comprehensively [28]. In context of water flows, industrial processes, which often have significant water consumption, should also be considered [29]. The design strategy presented here is oriented on the planning culture prevailing in Central Europe. For countries in other climate zones, some of which are even more affected by water scarcity and the consequences of climate change, integrated blue-green solutions offer high potentials [30,31]. The transferability to regions with other climatic conditions and problems should be addressed in further research.

Still pending is the examination of the microclimatic effects and the filtration of the grey water, which are essential to finally proof the impact of the project in terms of sustainability. First reliable results from the measurements will probably not be available until the end of 2021. Until then, the assumptions on climate effectiveness are based on the empirical 
values of completed studies, in which cooling by shading and evaporation of greening was proven [32-35]. The filter performance of constructed wetlands is also described in the literature [36,37], but will nevertheless be precisely determined in the Impulse Project by analysing water samples. Precise measurement results on water quantities and water quality will be published by the project partners (ISWA/TUK).

The design strategy was developed using the research by design methodology, which derives knowledge from the design process of a project. In this case, the development of the Impulse Project served as the object of research. As described in the introduction, research by design is a controversial research method whose ambiguity in definition is also due to the fact that it is still under development [38]. Nevertheless, it is appropriate and reliable for the present paper, because the process of gaining knowledge, which resulted from the clear approach according to Roggema [20], is comprehensible and transparent. Schöbel et al. [17] describe the characteristics of qualitative research as follows: "Qualitative research is essentially based on a creative but nevertheless systematic interpretation of data in search of new, previously unknown structures. It therefore has a proximity to research through architectural design." Therefore, in order to develop a design strategy for architectural projects, the application of a qualitative research methodology is the coherent approach (cf. [16]).

The resulting design strategy is intended to be applied in practice and aims to be transferable to other projects. This transferability has not yet been ascertained and will be discussed below. The Impulse Project differs in some points from a conventional planning and construction process. First of all, this is due to the intention and the financing of the construction measure. It took place within the framework of a research project, which influenced the distribution of roles (see Section 1.2). The total budget that was provided had an upper limit. This restriction is comparable to the budget of a potential client. Nevertheless, this comparability has its limits because the decision-making processes of a public research funder are different from those of a private investor. It is unlikely that a commercial client would finance a highly technical plant of this kind. The research background has, therefore, made the project possible. In practice, the financial aspects are more important and the additional cost of a blue-green project usually has to be amortised in the operational phase. Another difference to planning in practice is the composition of the team and the resulting powers, objectives and interests. It can be assumed that, instead of university partners, practicing (landscape) architecture offices and engineering offices that have no research interest in the object would be involved. Potential compositions of the team are described in Section 3.3 and shown in Figure 13. Nonetheless, as far as the procedure itself is concerned, we indeed see the transferability into practice. The development of the design in iterative loops refers to an approach that is established in architectural practice. Although the early integration of the specialist planners has not been tested with regard to water and vegetation, it is already being applied in the field of energy. However, proof of this is still pending and should be provided as soon as possible.

In conclusion, we would like to summarise our experience in planning the Impulse Project as follows: Crossing disciplinary boundaries is no easy task. It requires time and commitment, which makes it essential that everyone involved is willing to learn. However, it also represents a great opportunity for interdisciplinary cooperation. If all those involved consent to change their point of view and to explore new ways of finding solutions together, it will strengthen the project, make it more sustainable, more resilient, more climate effective, more resource efficient and add value for the urban space and its inhabitants. It is our aim to stimulate a new planning culture based on these principles.

Supplementary Materials: The following are available online at https: / www.mdpi.com/article/ 10.3390/su13147944/s1, Figure S1: photo constructed wetland July 2020, Figure S2: photo façade greening July 2020, Figure S3: photo impulse project July 2020, Figure S4: photo constructed wetland October 2020, Figure S5: photo greening on scaffolding October 2020, Figure S6: photo façade greening October 2020, Figure S7: photo container frames October 2020, Figure S8: photo impulse project October 2020, Figure S9: design variants v 1-5, Figure S10: design variants v 6, Figure S11: 
design variant v 7, Figure S12: design variant v 8, Figure S13: design variant v 9, Figure S14: design variant v 10, Figure S15: design variant v 11-12, Figure S16: design variant v 13, Figure S17: design variant v 14, Figure S18: design variant v 15, Figure S19: design variant v 16, Figure S20: detailed design container frame $\mathrm{v} 16$.

Author Contributions: Conceptualization, F.W. and F.L.; methodology, F.W.; investigation, F.W.; resources, F.W.; data curation, F.W.; writing-original draft preparation, F.W.; writing-review and editing, F.W. and F.L.; visualization, F.W.; supervision, F.L.; project administration, F.L.; funding acquisition, F.L. All authors have read and agreed to the published version of the manuscript.

Funding: This research was funded by Bundesministerium für Bildung und Forschung, grant number 01 LR 1705D.

Institutional Review Board Statement: Not applicable.

Informed Consent Statement: Not applicable.

Data Availability Statement: The data presented in this study are available in supplementary material.

Acknowledgments: We would like to thank all those involved for their committed cooperation in the Impulse Project, as well as the overall INTERESS-I project and the project coordinator Bernd Eisenberg. We also thank Kristina Pujkilovic for her work on the graphics. Special thanks go to Daniel Schönle and Jan-Timo Ort for the architectural concept and the close cooperation. We thank our neighbours and cooperation partners (ARGE Tunnel Cannstatt, Kunstverein Wagenhalle e.V., Stadtacker Wagenhallen e.V.) for their support and patience. For the financial and non-material support, we are grateful to the BMBF and DLR, who made the Impulse Project possible.

Conflicts of Interest: The authors declare no conflict of interest.

\section{References}

1. Bundesamt für Naturschutz. Urbane Grüne Infrastruktur: Grundlage für attraktive und zukunftsfähige Städte; Bundesamt für Naturschutz: Berlin, Germany, 2017.

2. Brears, R.C. Blue and Green Cities: The Role of Blue-Green Infrastructure in Managing Urban Water Resources, 1st ed.; Palgrave Macmillan Limited: London, UK, 2018; ISBN 9781137592576.

3. Dover, J.W. Introduction to Urban Sustainability Issues: Urban Ecosystem. In Nature Based Strategies for Urban and Building Sustainability; Perez, G., Perini, K., Eds.; Elsevier Science: Saint Louis, MO, USA, 2018; pp. 3-15, ISBN 9780128121504.

4. Gunawardena, K.R.; Wells, M.J.; Kershaw, T. Utilising green and bluespace to mitigate urban heat island intensity. Sci. Total Environ. 2017, 584-585, 1040-1055. [CrossRef] [PubMed]

5. Ghofrani, Z.; Sposito, V.; Faggian, R. A Comprehensive Review of Blue-Green Infrastructure Concepts. Int. J. Environ. Sustain. 2017, 6, 15-36. [CrossRef]

6. Well, F.; Ludwig, F. Blue-green architecture: A case study analysis considering the synergetic effects of water and vegetation. Front. Archit. Res. 2020, 9, 191-202. [CrossRef]

7. Rozos, E.; Makropoulos, C.; Maksimović, Č. Rethinking urban areas: An example of an integrated blue-green approach. Water Supply 2013, 13, 1534-1542. [CrossRef]

8. Dreiseitl, H. Blue-Green Infrastructures for Buildings and Liveable Cities. In Dense + Green: Innovative Building Types for Sustainable Urban Architecture; Schröpfer, T., Ed.; De Gruyter: Berlin, Germany; Boston, MA, USA, 2015; pp. 48-59, ISBN 9783038210146.

9. Sundermeier, M.; Kleinwächter, H. Integrale Projektabwicklung für Bauvorhaben mit komplexer Gebäudetechnik. Mod. Gebäudetechnik 2020, 5, 48-50.

10. Heidemann, A. Integrale Planung der TGA. In Integrale Planung der Gebäudetechnik: Erhalt der Trinkwassergüte-Vorbeugender Brandschutz-Energieeffizienz; Heidemann, A., Kistemann, T., Stolbrink, M., Kasperkowiak, F., Heikrodt, K., Eds.; Springer: Berlin, Germany, 2014; pp. 7-99, ISBN 978-3-662-44747-5.

11. Winker, M.; Gehrmann, S.; Schramm, E.; Zimmermann, M.; Rudolph-Cleff, A. Greening and Cooling the City Using Novel Urban Water Systems. In Approaches to Water Sensitive Urban Design: Potential, Design, Ecological Health, Urban Greening, Economics, Policies, and Community Perceptions; Sharma, A.K., Begbie, D., Gardner, T., Eds.; Elsevier: Duxford, UK, 2019; pp. 431-454, ISBN 9780128128435.

12. Heidemann, A.; Kistemann, T.; Stolbrink, M.; Kasperkowiak, F.; Heikrodt, K. Integrale Planung der Gebäudetechnik: Erhalt der Trinkwassergüte_Vorbeugender Brandschutz—Energieeffizienz; Springer Vieweg: Berlin, Germany, 2014; ISBN 978-3-662-44747-5.

13. Kimbell, L. Rethinking Design Thinking: Part I. Des. Cult. 2011, 3, 285-306. [CrossRef]

14. Kurath, M.M. Architecture as a Science: Boundary Work and the Demarcation of Design Knowledge from Research. Sci. Technol. Stud. 2015, 28, 81-100. Available online: https:/ / www.alexandria.unisg.ch/publications/252378 (accessed on 28 January 2020). [CrossRef] 
15. Schäffner, W. Vom Wissen zum Entwurf: Das Projekt der Forschung. In Entwurfsbasiert Forschen; Weidinger, J., Ed.; Universitätsverlag der TU Berlin: Berlin, Germany, 2013; pp. 55-64, ISBN 9783798326521.

16. Hameed, H. Quantitative and qualitative research methods: Considerations and issues in qualitative research. Maldives Natl. J. Res. 2020, 8, 8-17.

17. Schöbel, S.; Schäfer, J.; Hausladen, G. Research through Design under Systematic Quality Criteria: Methodology and Teaching Reseach. Dimensions. J. Arch. Knowl. 2021, 1, 99-109. [CrossRef]

18. Knoop, H. Architects as Public Intellectuals: How Far Beyond Can We Go? Dimensions. J. Arch. Knowl. 2021, 1, 111-118. [CrossRef]

19. Prominski, M. Research and design in JoLA. J. Landsc. Archit. 2016, 11, 26-29. [CrossRef]

20. Roggema, R. Research by Design: Proposition for a Methodological Approach. Urban Sci. 2017, 1, 1-19. [CrossRef]

21. Landeshauptstadt Stuttgart. Das Rosenstein-Quartier. Available online: https://www.stuttgart.de/leben/stadtentwicklung/ rosenstein-quartier.php (accessed on 16 December 2020).

22. Grant, G. The Water Sensitive City; John Wiley \& Sons, Ltd.: Chichester, UK, 2016; ISBN 9781118897669.

23. Landeshauptstadt Stuttgart. Stadtklima Stuttgart: Download von Messdaten der Station S-Mitte. Available online: https: //www.stadtklima-stuttgart.de/index.php?klima_messdaten_download (accessed on 24 February 2021).

24. Winker, M.; Frick-Trzebitzky, F.; Matzinger, A.; Schramm, E.; Stieß, I. Die Kopplungsmöglichkeiten von grüner, grauer und blauer Infrastruktur mittels raumbezogenen Bausteinen: Ergebnisse aus dem Arbeitspaket 2, netWORKS 4; Deutsches Institut für Urbanistik gGmbH (Difu): Berlin, Germany, 2019; ISBN 978-3-88118-650-6.

25. Pötz, H.; Bleuzé, P. Urban Green-Blue Grids for Sustainable and Dynamic Cities; Coop for life: Delft, The Netherlands, 2012.

26. Kruse, E. Integriertes Regenwassermanagement für den wassersensiblen Umbau von Städten: Großräumige Gestaltungsstrategien, Planungsinstrumente und Arbeitsschritte für die Qualifizierung innerstädtischer Bestandsquartiere; HafenCity University, Hamburg, Germany, 2014; Fraunhofer IRB Verl.: Stuttgart, Germany, 2015; ISBN 9783816794752.

27. Kuller, M.; Bach, P.M.; Roberts, S.; Browne, D.; Deletic, A. A planning-support tool for spatial suitability assessment of green urban stormwater infrastructure. Sci. Total Environ. 2019, 686, 856-868. [CrossRef] [PubMed]

28. Bus, A.; Szelagowska, A. Green Water from Green Roofs-The Ecological and Economic Effects. Sustainability $2021,13,2403$. [CrossRef]

29. Borowski, P.F. Nexus between water, energy, food and climate change as challenges facing the modern global, European and Polish economy. AIMS Geosci. 2020, 6, 397-421. [CrossRef]

30. WWAP (UNESCO World Water Assessment Programme). The United Nations World Water Development Report 2019: Leaving No One Behind; UNESCO: Paris, France, 2019; ISBN 9231003097.

31. WWAP (United Nations World Water Assessment Programme)/UN-Water. The United Nations World Water Development Report 2018: Nature-Based Solutions for Water; United Nations Educational, Scientific and Cultural Organization: Paris, France, 2018; ISBN 978-92-3-100264-9.

32. Grilo, F.; Pinho, P.; Aleixo, C.; Catita, C.; Silva, P.; Lopes, N.; Freitas, C.; Santos-Reis, M.; McPhearson, T.; Branquinho, C. Using green to cool the grey: Modelling the cooling effect of green spaces with a high spatial resolution. Sci. Total Environ. 2020, 724, 138182. [CrossRef] [PubMed]

33. Susca, T.; Gaffin, S.R.; Dell'Osso, G.R. Positive effects of vegetation: Urban heat island and green roofs. Environ. Pollut. 2011, 159, 2119-2126. [CrossRef] [PubMed]

34. Perini, K.; Ottelé, M.; Haas, E.M.; Raiteri, R. Vertical greening systems, a process tree for green façades and living walls. Urban Ecosyst. 2013, 16, 265-277. [CrossRef]

35. Köhler, M.; Rares Nistor, C. Wandgebundene Begrünungen: Quantifizierungen einer neuen Bauweise in der Klima-Architektur; Fraunhofer IRB Verlag: Stuttgart, Germany, 2015; ISBN 978-3-7388-0059-3.

36. Kocsis, G. Wasser nutzen, verbrauchen oder verschwenden? Neue Wege zu einem schonenden und sparsamen Umgang mit Wasser und einer naturnahen Abwasserreinigung; 2., durchges. Aufl.; Müller: Karlsruhe, Germany, 1988; ISBN 3788097574.

37. Li, F.; Wichmann, K.; Otterpohl, R. Review of the technological approaches for grey water treatment and reuses. Sci. Total Environ. 2009, 407, 3439-3449. [CrossRef] [PubMed]

38. Biggs, M.A.R. An activity theory of research methods in architecture and urbanism. City Territ. Arch. 2014, 1, 6. [CrossRef] 